\title{
Dos Contextos Locais à Invisibilização Política Discussão em torno dos ciclos de exclusão habitacional dos ciganos em Portugal
}

Alexandra Castro *

\begin{abstract}
$\mathrm{R}$ Resumo: Este artigo pretende dar um contributo à reflexão e à avaliação sobre a persistência da situação habitacional precária dos portugueses ciganos ao longo dos tempos. Neste sentido, serão analisados os principais factores exógenos à população cigana que poderão justificar a perpetuação das situações de exclusão habitacional. Partindo-se de um enquadramento sobre a dimensão deste fenómeno explicitam-se aqueles factores, através de três eixos: 1) os discursos técnica e cientificamente pouco fundamentados para justificar a precariedade habitacional e a inacção política, onde o nomadismo aparece como denominador comum, seja enfatizando-se a presença de ciganos itinerantes, seja admitindo-se a sua inexistência; 2) as estratégias públicas de âmbito local para a não fixação e para a mobilidade forçada; 3) a inexistência de tradução dos problemas e necessidades sentidos localmente nos sucessivos Planos Nacionais de Acção para a Inclusão e em medidas de política de habitação que pudessem colmatar alguns dos problemas identificados. Os exemplos de recomendações de algumas organizações governamentais e não governamentais pretendem ilustrar algumas das condições por onde pode passar a mudança.
\end{abstract}

Palavras-chave: Ciganos; Habitação inadequada; Processos de realojamento; Inclusão social; Políticas de habitação.

Este artigo apoia-se nos resultados de duas pesquisas realizadas no Centro de Estudos Territoriais. Os resultados alcançados na primeira investigação foram retomados para um maior aprofundamento no projecto que ainda está a decorrer'. Aborda-se aqui, ainda que parcelarmente, apenas um dos eixos de análise da investigação em curso que passa pela compreensão do papel de determinados contextos territoriais e políticos na configuração geográfica dos percursos de mobilidade e nos processos de sedentarização, evidenciando-se, entre outros aspectos, as medidas de política social/habitacional que implicam a permanência num dado território, mas também as representações sociais sobre a comunidade cigana. $\mathrm{O}$ aprofundamento deste eixo de análise implicou em termos metodológicos a análise dos documentos produzidos no âmbito dos concelhos que aderiram ao Programa Rede Social, a análise documental de projectos de intervenção habitacional, a análise de conteúdo de cerca de 30 entrevistas semidirectivas a técnicos e dirigentes de autarquias/ associações, e a informantes privilegiados ciganos e a aplicação de dois inquéritos por questionário Ciganos, Terri-tórios e Itinerância - às Câmaras Municipais (CTI l) e aos postos da Guarda Nacional Republicana (CTI 2) de Portugal continental. Os outros eixos de análise centrados essencialmente nos factores endógenos à população que interferem nas lógicas de estruturação dos seus modos de vida e consequentemente nos seus percursos territoriais implicaram procedimentos de recolha

\footnotetext{
Socióloga, Investigadora do CET. Contacto: castro.alexandra@gmail.com

Duarte et al. (2005a), estando parte dos resultados publicados em Castro (2004). A pesquisa ainda em curso intitula-se "Ciganos e territórios: mobilidade e sedentarização no contexto urbano português", coordenada por Vítor Matias Ferreira e Alexandra Castro, fazendo parte da equipa o bolseiro André Correia. Participaram no âmbito do trabalho de terreno Mafalda Sousa e Hugo Castro. Este projecto de investigação iniciado em Janeiro de 2006 é financiado pela Fundaçāo para a Ciência e Tecnologia, do Ministério da Ciência e Tecnologia.
} 
e análise da informação no âmbito do método de pesquisa de terreno, através da realização de observação participante, histórias de família e entrevistas semi-directivas a ciganos.

Ao longo desta exposição procuraremos, num primeiro momento, actualizar a informação sobre a dimensão da população cigana em Portugal continental, no sentido de percebermos o peso que as situações de precariedade habitacional têm entre esta população. Iremos, assim, sistematizar um conjunto de fontes quer sobre a expressão dos ciganos no país, quer sobre as suas condições de habitação. Num segundo momento, evidenciaremos os principais factores exógenos à população cigana que têm condicionado o seu acesso a uma habitação condigna e adequada. As modalidades de organização das famílias ciganas e a forma como estruturam a sua relação com o território e o habitat são também eles factores indispensáveis na compreensão deste fenómeno, mas que se encontram neste momento a ser analisados.

\section{A Dimensão da População Cigana em Portugal}

A necessidade de se fazer referência à dimensão da população cigana tem sido uma preocupação de vários estudos desenvolvidos em Portugal ${ }^{2}$, no sentido de se contextualizar os territórios onde se desenrolam as pesquisas, de enquadrar a temática que se pretende apresentar ou de contribuir para uma acção pública mais sustentada ao nível da concepção, acompanhamento e avaliação de políticas e programas relativos à inclusão social. A inexistência de fontes oficiais que permitam uma aproximação a esta realidade de forma mais fidedigna tem conduzido algumas equipas de investigação a recorrerem a diversas formas de recolha de informação, obtendo resultados diferentes e de uma grande variabilidade ${ }^{3}$.

Em 1997, o SOS Racismo procurou recolher informação junto das câmaras municipais de Portugal continental e contabilizou 13514 ciganos para os 139 municípios que responderam ao questionário enviado (SOS Racismo, 2001). De referir, que Olímpio Nunes entre 1973 e 1980 procedeu a um levantamento tendo contabilizado 18800 ciganos com residência fixa e aproximadamente $1600 \mathrm{sem}$ domicílio fixo (Nunes, 1981) .

No âmbito do projecto de investigação do Centro de Estudos Territoriais finalizado em 2005 (Duarte et al., 2005), procurou-se actualizar e colmatar a ausência de dados recolhidos pelo SOS Racismo, através do envio do questionário Ciganos, Territórios e Itinerância 1 (CTI 1) a todas as câmaras municipais do continente, obtendo-se uma cobertura de $65,5 \%$ e chegou-se ao número de 19747 ciganos (Castro, 2004) ${ }^{5}$. Mais tarde, em 2006, procurou-se mais uma vez confrontar e actualizar os resultados então obtidos agora junto dos postos da Guarda Nacional Republicana, através do envio do questionário Ciganos, Territórios $e$ Itinerância 2 (CTI 2). Foram recepcionados 382 questionários, o que equivale a uma taxa de resposta de $77 \%$ (cf. Castro, 2006) ${ }^{6}$. Do balanço da aplicação deste novo instrumento de recolha de informação constata-se a actualização dos dados para 64 concelhos e a obtenção de nova informação para mais 57 concelhos para os quais nunca se tinha tido dados disponíveis. Os restantes concelhos com informação (93) são o resultado dos dados disponíveis no SOS Racismo ${ }^{7}$, no CTI 1 e nos

\footnotetext{
2 Ver entre outros Nunes (1981), Amiguinho (1994), Sama (2003), Castro (2004), Reapn (2007).

3 A nível internacional alguns estudos apontam para a existência em Portugal entre 50 a 100 mil ciganos, sem no entanto se explicitar o método de recolha de informação. Para o European Commission Against Racisms and Intolerance (ERCI) existem em Portugal entre 50000 a 60000 ciganos (2002:23) e para Machiels os dados variam entre os 50000 e os 100000 (2002: 11).

4 Este levantamento contou com a recolha directa junto de famílias ciganas, mas também pelo recurso a informadores que indicaram o número aproximado de famílias, estimando-se a dimensão de 6 elementos por família.

${ }^{5}$ A taxa de resposta ao questionário foi de 55\% e colmatou-se a ausência de informação com os dados recolhidos pelo SOS Racismo para 44 concelhos do país. Ficou-se então com informação para 182 concelhos do continente.

${ }^{6}$ De acordo com a informação disponibilizada no site da GNR existem 496 postos a nível nacional. Embora os postos da GNR tenham circunscrição concelhia, muitas vezes a sua área de intervenção não corresponde à totalidade do concelho, nomeadamente em determinadas áreas urbanas, como as capitais de distrito, em que a atribuição de competências fica a cargo da Polícia de Segurança Pública. Assim, aquando da confrontação dos dados do CTI 1 e 2, optou-se por manter o valor mais elevado quando o valor apresentado no CTI 1 era superior. No entanto, quando era mais elevado no CTI 2 e não correspondia a áreas de intervenção da PSP, optou-se por mantê-lo, pois poderia ser mais actual. Quando a diferença era inferior a 5, ou seja, menos ciganos no CTI 2, decidiu-se pelo valor apresentado no CTI 2 pela razão apontada anteriormente.

7 A ausência de informação relativa a alguns concelhos ou a apresentação de um número subestimado implicou o recurso aos dados do SOS racismo para 13 concelhos: Braga, Cadaval, Celorico da Beira, Entroncamento, Ílhavo, Mogadouro, Lamego, Oliveira de Azeméis, Póvoa do Lanhoso, Santa Maria da Feira, Santo Tirso, Torres Vedras, Vila Velha de Ródão, totalizando 3117 ciganos.
} 
documentos do Programa Rede Social. Obtém-se, assim, uma cobertura do território nacional de $75,5 \%$.

Salvaguardando que não existe informação disponível para cerca de $1 / 4$ do território continental e que parte dos dados recolhidos não podem ser considerados exaustivos, a dimensão da população cigana estima-se em cerca de 34000 elementos. Uma análise da distribuição dos ciganos por distrito coloca actualmente à frente o distrito de Setúbal com 5895, seguido dos distritos de Lisboa (2854), Porto (2665), Faro (2647), Santarém (2245), Braga (2191), Portalegre (2089). Apesar de Lisboa aparecer mais uma vez em segundo lugar, agora com mais 972 ciganos face ao número apresentado no CTI 1, o valor do distrito de Lisboa está aqui subestimado pela ausência de dados da capital do país. De referir que no âmbito de um estudo da Pastoral dos Ciganos (Marques et al, 1996), o concelho de Lisboa contava com 2332 e o distrito com 5640, situação que aproximaria os distritos de Lisboa e Setúbal ${ }^{8}$.

Vila Real continua a ser o distrito que regista o menor número de ciganos. Embora na análise dos dados do CTI 1 se tenha atribuído este número à baixa taxa de resposta $(21,4 \%)$, através do CTI 2 esta situação não se verificou, registandose informação nova para 10 concelhos ${ }^{9}$, o que poderá traduzir uma expressão mais aproximada à realidade.

Figura 1 - Distribuição do número de ciganos por distrito

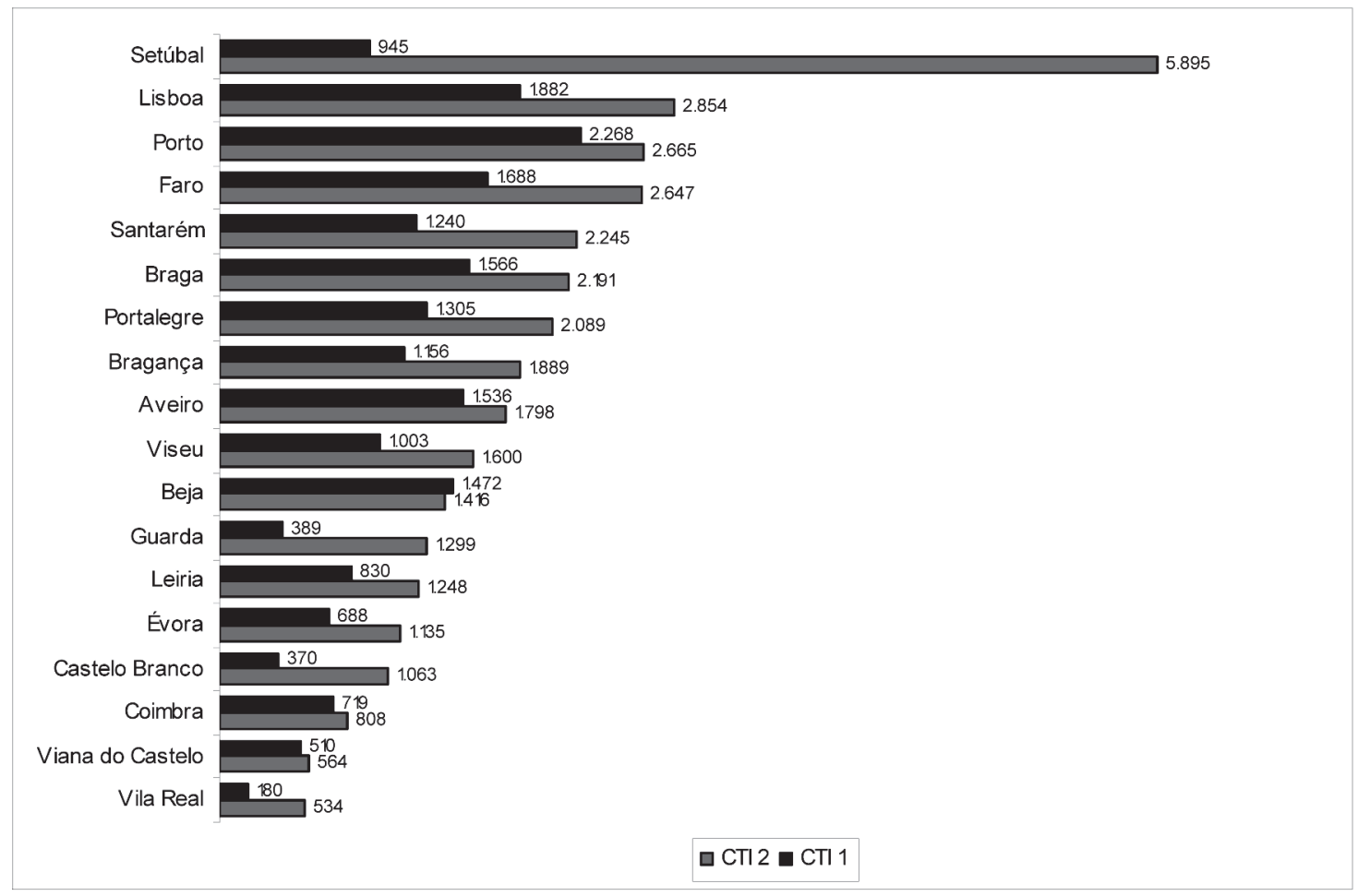

CTI $2=33.940$

CTI $1=19.747$

Fonte: Questionário CTI 1, CET 2005; Questionário CTI 2; CET, 2006; SOS Racismo 1997.

\footnotetext{
${ }^{8}$ Um outro estudo realizado para o concelho de Sintra em 2006, através da utilização de metodologias intensivas contabilizou 602 ciganos (Bastos, et al., 2006), quando no CTI 2 foram identificados $172 \mathrm{com}$ as respostas de 3 dos 7 postos existentes no concelho.

9 Cinco concelhos quantificam a comunidade existente, quatro referem não existir ciganos e um não refere o número.
} 


\section{Uma Aproximação à Situação Habitacional dos Ciganos em Portugal}

Um levantamento efectuado através de recolha directa, em 2000, pela Obra Nacional da Pastoral dos Ciganos sobre as situações de alojamento precário da população cigana no território continental português apontava para a existência de 834 famílias, correspondendo a 4398 pessoas a residir há mais de dois anos, numa dada localidade, em situação habitacional precária ou degradada. Estes dados não incluem os concelhos da diocese de Lisboa $^{10}$, áreas de grande concentração de população cigana. De referir que $61 \%$ da população recenseada encontrava-se nesta situação há mais de 20 anos e $63 \%$ das famílias concentravam-se em 6 dos 17 distritos portugueses (ONPC, 2000), nomeadamente nos distritos de Viana do Castelo, Viseu, Porto, Aveiro, Évora e Faro. Na página da Internet da ONPC 11 , pode ler-se que "os ciganos a viverem em barracas/tendas a nível nacional rondam os 7000 , correspondendo a $18 \%$ da população cigana", para um universo estimado de cerca de 40 mil pessoas.

Sensivelmente no mesmo período o SOS Racismo publica o já referenciado levantamento efectuado junto dos municípios portugueses, concluindo que cerca de $4200^{12}$ dos ciganos em Portugal vivem em condições habitacionais precárias, nomeadamente em Viana do Castelo, Castelo Branco, Coimbra e Évora (SOS Racismo, 2001: 22). Também no âmbito deste levantamento se recolheram as medidas das autarquias dirigidas tanto à população cigana como à não cigana e constatou-se que a intervenção para a resolução de proble- mas habitacionais era a que mais motivava as autarquias portuguesas, já que dos 95 municípios que responderam a esta questão, 46 já tinham realizado ou planeavam realizar o realojamento de famílias ciganas residentes em zonas degradadas. Outra medida frequente foi o apoio à recuperação de casas, havendo algumas autarquias que referiam o apoio na criação de infra-estruturas, tais como a instalação de esgotos ou de electricidade nas zonas onde a população cigana se instala (Albuquerque, 2001: 54).

\section{Quadro 1: População cigana em situação habitacional precária ou degradada}

\begin{tabular}{|c|c|c|}
\hline $\begin{array}{c}\mathrm{N}^{\circ} \text { Anos na } \\
\text { situação }\end{array}$ & Famílias & Pessoas \\
\hline - 2 anos & 29 & 142 \\
\hline+2 anos & 181 & 961 \\
\hline+10 anos & 101 & 514 \\
\hline+15 anos & 21 & 99 \\
\hline+20 anos & 214 & 1.072 \\
\hline+30 anos & 103 & 562 \\
\hline+40 anos & 87 & 512 \\
\hline+50 anos & 93 & 536 \\
\hline
\end{tabular}

Fonte: Projecto Dignidade, Relatório, Obra Nacional da Pastoral dos Ciganos, Dezembro 2000.

\footnotetext{
${ }^{10} \mathrm{O}$ argumento avançado para a não inclusão desta área geográfica prende-se com o facto da ONPC ter realizado em 1994 um levantamento sobre a situação socioeconómicas da população cigana residente nos 23 concelhos que constituem a área da Diocese de Lisboa e ter concluído que dos 1446 agregados familiares aqui residentes (6043) pessoas), 46,1\% vivia em barracas e 12,8\% em casas em ruínas, prédios inacabados, tendas ou roulotes (Marques et al. 1996: 72). Os dados do concelho do Porto não foram objecto de levantamento por recolha directa, mas sim obtidos através do recurso a informadores privilegiados.

$11 \mathrm{http}: / /$ www.ecclesia.pt/pnciganos).

12 Este número foi calculado pela proporção indicada de $31 \%$ de ciganos a viverem nestas condições face aos 13514 que foi possível apurar com o levantamento efectuado.
} 
De acordo com os dados recolhidos no âmbito do estudo do CET constata-se a existência de 6516 ciganos a viverem em condições precárias de habitação sejam estas fixas ou móveis, correspondendo a 19,2\% face ao número total de ciganos que foi possível apurar (33 940). Estes dados relativos à situação habitacional, como se poderá constatar de seguida, resultam dos resultados do questionário CTI 2, da informação recolhida no trabalho de terreno e da análise dos documentos do Programa Rede Social.

A figura seguinte dá conta da distribuição destas situações pelo território continental, aparecendo os distritos de Leiria e Évora onde cerca de metade da população cigana apresenta condições de habitação precária. Castelo Branco, Beja, Santarém, Viseu, Portalegre e Faro merecem também algum destaque por apresentarem valores superiores a $20 \%$.
Os dados apresentados pela ONPC, pelo SOS Racismo e pelo CET revelam uma distribuição territorial diferente do peso dos ciganos em situação de precariedade habitacional que poderá eventualmente ser explicada pelo tempo que medeia a recolha de informação, pela utilização de fontes diversas de informação e pelo entendimento que se faz da população com habitação móvel. No entanto, constata-se a predominância do distrito de Évora nas três fontes apresentadas ${ }^{13}$ e de Viana do Castelo e de Faro em duas delas.

Os resultados alcançados pelo CTI 2 identificam 4200 ciganos sem residência fixa, circulando regularmente pelo território nacional. A par da relativa estabilidade nos locais por onde vão permanecendo, constata-se que tendem a ser sempre as mesmas famílias que ocupam os mesmos locais, registando-se em média 25,4 elementos por acampamento. Através do cruzamento dos dados obti-

Figura 2: Distribuição do peso das situações de precariedade habitacional entre a população cigana

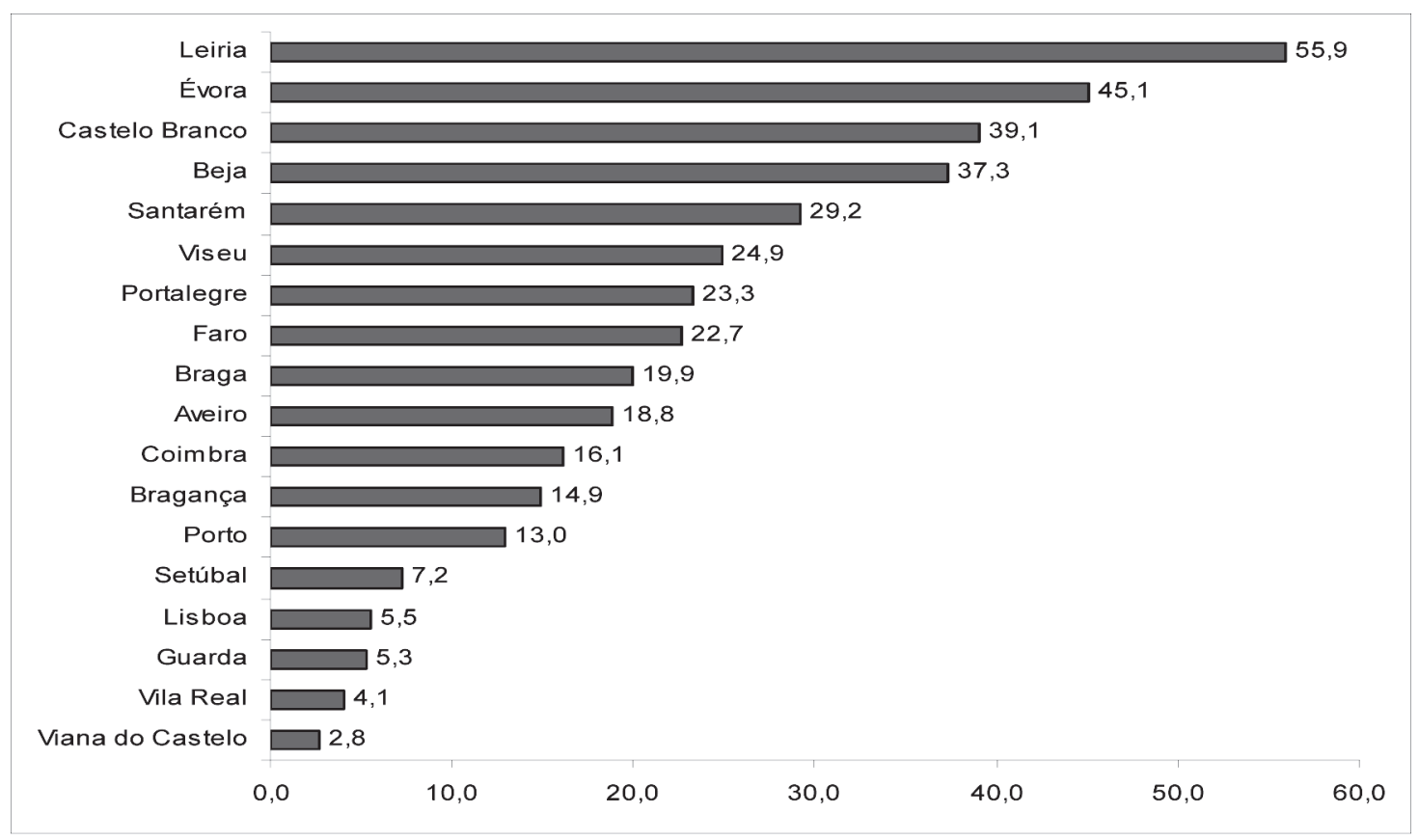

Fonte: Dados recolhidos no âmbito do Projecto: "Ciganos e territórios: mobilidade e sedentarização no contexto urbano português", CET 2006-2007.

\footnotetext{
13 Num estudo realizado nos três distritos do Alentejo, em 1993 (Amiguinho, 1994:100), constata-se a existência em Évora de 796 ciganos, correspondendo a 159 famílias, sendo que mais de metade vive em barracas (84) e 13 em tendas, destacando-se de Portalegre (com 47 em barracas e 14 em tendas), mas aproximando-se de Beja (com 77 em barracas e 24 em tendas).
} 
dos com este questionário com informação recolhida junto de outras entidades, aquele número parece estar subestimado. A título de exemplo, refira-se o caso do concelho de Beja que regista no questionário a existência de 14 pessoas contra 41 indivíduos sinalizados como "nómadas" a beneficiar de Rendimento Social de Inserção, bem como a ausência de dados para concelhos que tendem a concentrar um grande número de famílias.

No âmbito do trabalho de terreno, iniciado em Junho de 2006, contactámos com 13 famílias alargadas, correspondendo a 49 núcleos familiares, que contabilizam 219 pessoas nas regiões Centro e Alentejo. A maioria destas famílias vive em tendas e embora a sua presença seja mais constante em determinados concelhos, nem todas aparecem recenseadas pelas fontes anteriormente citadas.

Como se pode verificar pelo quadro seguinte, apesar da existência de algumas variações entre os espaços visitados ao nível das formas de construção dos diferentes tipos de "abrigo", constata-se a predominância das mesmas características nos restantes parâmetros. Ou seja, tratam-se de famílias que nunca tiveram acesso a uma casa ou quando residiram numa habitação tinham um estatuto ilegal de ocupação; todos os acampamentos visitados localizam-se geralmente nas periferias das localidades, à excepção de deslocações temporárias para áreas mais centrais; estão desprovidos das infra-estruturas básicas, como o acesso a água canalizada, a electricidade da rede pública e a infra-estruturas de saneamento; não são proprietários dos espaços onde residem e podem ter ou não uma autorização informal de permanência; sofrem regularmente a pressão das autoridades locais para abandonarem os locais ocupados, à excepção dos acampamentos onde foi possível um acordo tácito entre as famílias ciganas e os proprietários dos terrenos, sejam eles públicos ou privados.

Quadro 2: Uma aproximação à tipologia de acampamentos

\begin{tabular}{|c|c|c|c|}
\hline \multirow{2}{*}{ Parâmetros } & \multicolumn{3}{|c|}{ Tipos de acampamento } \\
\hline & Móvel & Fixo & Misto \\
\hline Tipo de "abrigo" & Tendas & Barracas & Casa, roulottes, tenda \\
\hline Materiais de construção & Oleados, estacas & $\begin{array}{l}\text { Chapa de zinco, } \\
\text { madeira, cimento }\end{array}$ & $\begin{array}{c}\text { Tijolo, alvenaria, chapa } \\
\text { de zinco, oleados, } \\
\text { estaca }\end{array}$ \\
\hline Título de propriedade & Inexistente & Inexistente & Inexistente \\
\hline $\begin{array}{c}\text { Autorização de } \\
\text { permanência }\end{array}$ & $\begin{array}{c}\text { Sem autorização } \\
\text { Autorização informal }\end{array}$ & $\begin{array}{l}\text { Autorização formal } \\
\text { do município }\end{array}$ & $\begin{array}{l}\text { Autorização formal da } \\
\text { paróquia - doação } \\
\text { Autorização informal }\end{array}$ \\
\hline Mobilidade/fixação & Maior mobilidade & Maior fixação & Maior fixação \\
\hline Transporte & $\begin{array}{c}\text { Carroças, cavalos, burros, } \\
\text { triciclo motor, carro, } \\
\text { carrinha. }\end{array}$ & $\begin{array}{l}\text { Carroças, cavalos, } \\
\text { burros, carrinhas, } \\
\text { carros. }\end{array}$ & $\begin{array}{l}\text { Carroças, cavalos, } \\
\text { carrinhas }\end{array}$ \\
\hline Infra-estruturas & $\begin{array}{c}\text { Gerador eléctrico. Acesso } \\
\text { a água na vizinhança ou a } \\
\text { bica próxima }\end{array}$ & $\begin{array}{c}\text { Gerador eléctrico. } \\
\text { Água (torneira, } \\
\text { bica) }\end{array}$ & $\begin{array}{l}\text { Água (torneira, bica) } \\
\text { Gerador eléctrico }\end{array}$ \\
\hline Proximidade/centralidade & $\begin{array}{l}\text { Nas margens. Variável } \\
\text { devido à maior } \\
\text { mobilidade. }\end{array}$ & $\begin{array}{l}\text { Nas margens, mas } \\
\text { também ocupação } \\
\text { temporário de } \\
\text { zonas centrais das } \\
\text { localidades }\end{array}$ & Nas margens \\
\hline $\begin{array}{c}\text { Pressão de } \\
\text { entidades/autoridades } \\
\text { locais }\end{array}$ & $\begin{array}{l}\text { Expulsões, agressões } \\
\text { continuadas e tolerância } \\
\text { passado um ano de } \\
\text { pressão para a saída do } \\
\text { concelho }\end{array}$ & $\begin{array}{l}\text { Aceitação do } \\
\text { acampamento, com } \\
\text { projecto de } \\
\text { realojamento em } \\
\text { curso }\end{array}$ & $\begin{array}{l}\text { Aceitação da habitação, } \\
\text { mas com destruição das } \\
\text { barracas e expulsões da } \\
\text { população que vive em } \\
\text { oleados }\end{array}$ \\
\hline $\begin{array}{l}\text { Acesso a uma casa ao } \\
\text { longo da trajectória } \\
\text { residencial }\end{array}$ & $\begin{array}{l}\text { Inexistente ou casa } \\
\text { ocupada ilegalmente }\end{array}$ & $\begin{array}{l}\text { Casa do } \\
\text { empregador }\end{array}$ & Inexistente \\
\hline
\end{tabular}

Fonte: CET, 2007, Projecto Ciganos e territórios: mobilidade e sedentarização no contexto urbano português". 
No estudo que nos encontramos a desenvolver procedemos também a uma recolha da informação contida nos diferentes instrumentos produzidos no âmbito do Programa Rede Social ${ }^{14}$ : Diagnósticos Sociais, Planos de Desenvolvimento Social e Planos de Acção. Procurámos, assim, analisar a informação contida nestes instrumentos de planeamento tentando dar visibilidade a algumas problemáticas/preocupações localmente sentidas, bem como fornecer um panorama a nível nacional mais fundamentado ${ }^{15}$. Independentemente do tipo e da qualidade dos dados, são 65 os concelhos que fazem referência à população cigana e 13 a minorias étnicas ou culturais ${ }^{16}$. Como 102 concelhos com documentos disponíveis on-line não mencionam a população cigana, podemos depreender, por um lado, que embora esta possa estar presente nos seus territórios não constitui uma temática que mereça a atenção/preocupação das equipas das redes sociais ou que na altura da realização dos documentos não se registava a presença de população cigana. Algumas limitações podem ser apontadas a esta análise, nomeadamente a desactualização de alguma informação que é apresentada, a ausência de dados relevantes nalgumas áreas do país e o facto de alguns concelhos não parecerem ter interiorizado a metodologia a desencadear no âmbito dos instrumentos de planeamento locais, uma vez que reproduziram as metas e medidas incluídas no PNAI de 2003-2005.

Relativamente à habitação encontramos informação apenas para trinta e oito concelhos, distribuídos por todos os distritos do país. Da análise dos diagnósticos elaborados pelas redes sociais os problemas associados com as formas de ocupação do espaço traduzem-se em:
- Ocupação ilegal de terrenos, de casas ou de instalações degradadas (Mealhada, Barcelos, Mogadouro, Idanha-a-Nova, Vila Real de Santo António, Peniche);

- Construção de habitações clandestinas ou barracas (Serpa, Carrazeda de Ansiães, Montemor-o-Velho, Estremoz, Loulé, Peniche, Amadora, Campo Maior, Felgueiras, Coruche, Seixal, Nelas, Moimenta da Beira, Lamego);

- Realojamento provisório em casas de madeira na sequência de cheias (Montemor-o-Velho), ou em contentores (Alter do Chão);

- Bairros de habitação social socialmente homogéneos e periféricos face às centralidades urbanas (Oeiras, Elvas).

Para além dos problemas habitacionais acima referidos, são apontadas outras dificuldades e necessidades, delineando-se, em algumas redes sociais, nos planos de desenvolvimento social (PDS) ou nos planos de acção (PA) as actividades a desenvolver. A "população nómada" cigana aparece como tendo necessidade de uma resposta específica em termos habitacionais nem sempre ficando claro qual é o problema que se pretende resolver através da criação de um "Parque Nómada". É o caso de uma rede social que enuncia como objectivo geral para a construção do Parque Nómada a criação de "equipamentos que favoreçam a integração sociocultural das comunidades ciganas" e como estratégia "integrar as diferenças culturais da comunidade cigana na comunidade" (PDS, 2004-2007). A excepção vai para um concelho que refere que esta estrutura visaria a população cigana "que diariamente surge no nosso concelho, a qual não tem condições de permanência, relativa-

\footnotetext{
14 Este Programa surge como um instrumento de desenvolvimento local e de consolidação da coesão social, pela adopção de processos de planeamento estratégico territorializado como base da intervenção social, servindo para "incentivar o surgimento de redes de apoio integrado de âmbito local". Criado através da Resolução do Conselho de Ministros n. ${ }^{\circ}$ 197/97 de 18 de Novembro de 1997 e regulamentado pelo Decreto-lei n. ${ }^{\circ} 115 / 2006$ de 14 de Junho. Trata-se de um programa que contou com o co-financiamento, no período entre 2002 e 2007 , do Fundo Social Europeu - Programa Operacional Emprego, Formação e Desenvolvimento Social e o Estado Português - Ministério da Segurança Social e do Trabalho. Este programa assumiu, no decurso de 2000 um carácter experimental englobando 41 concelhos-piloto. Em Maio de 2006, todos os concelhos tinham aderido ao Programa, à excepção de Tomar e Viseu. Os concelhos de Porto e Lisboa aguardavam ainda a constituição dos respectivos CLAS e actualmente apenas Viseu não integrou o programa.

15 Através dos documentos disponibilizados no site da Segurança Social (http://195.245.197.216/rsocial/) procedeu-se a uma pesquisa das palavras "cigana" e "cigano" que decorreu na primeira metade de Maio e no mês de Novembro de 2006. De referir que 87 concelhos não tinham no momento da recolha documentos acessíveis on-line.

${ }^{16}$ As temáticas da educação e da habitação são as mais referenciadas, seguidas pelas da acção social/Rendimento Social de Inserção, do emprego e formação profissional. Cada uma destas áreas tem uma expressão territorial diferente e níveis desiguais de aprofundamento. Apenas vinte sete concelhos fazem referência à dimensão da população cigana residente ou presente, apresentando alguns informação relativa à data de chegada ao concelho, à origem geográfica das famílias, à evolução da população, à caracterização etária, ao tipo e dimensão da família.
} 
mente ao espaço a ocupar, com as condições de higiene e segurança necessárias, sem que os mesmos possam vir a entrar em conflito com a população residente, a qual por norma é bastante irredutível à sua presença." (PDS, Julho 2003). Existe ainda uma outra rede social que perante a constatação no diagnóstico social da inexistência de habitações para a população nómada considera necessário iniciar actividades de carácter socioeducativo e outras com esta população, admitindo que a "construção de raiz de edifícios para habitação social não se vislumbra necessária, tendo em conta a existência de património edificado, que deve ser rentabilizado (conjuntamente com Programas de financiamento existentes), garantindo as necessárias condições de habitabilidade aos seus residentes" (PDS, 2005-2010) ${ }^{17}$.

Algumas redes sociais que se defrontam com problemas na área da habitação perspectivam a realização de estudos. É o caso de um concelho que pretende aprofundar o "problema habitacional nas suas diversas dimensões, nomeadamente através do conhecimento das expectativas da população-alvo, das experiências positivas realizadas nesta área, e da elaboração de propostas de intervenção (PDS, 2005-2008; PA, 2005-2006). Outras redes sociais vêem na realização de estudos uma possibilidade de se aprofundar as questões relativas à "inserção" e às "políticas sociais", não as centrando exclusivamente na área da habitação. É o caso de uma rede social que considera fundamental a caracterização da comunidade cigana a viver numa das zonas do concelho, pois "só então se poderá pensar numa política social adequada a estas famílias” (PDS, Agosto 2004), mas também de outra rede que pretende com o estudo uma "análise das dificuldades relativas à inserção dos ciganos na sociedade em geral e, no concelho", bem como uma "acção integrada de inserção social dos ciganos na sociedade" (Diagnóstico Social, 2004; PDS, Janeiro 2005). Apesar destas intenções, nenhuma das redes sociais conseguiu concretizar os referidos estudos.
As redes sociais que identificam problemas relacionados com a habitação e a população cigana sem a sua correspondência nos instrumentos de planificação futura referem, por um lado, a inexistência a nível local de políticas sociais integradas na área da habitação no concelho ou a falta de continuidade de um projecto que contemplava uma intervenção integrada e sistémica. Por outro lado, é também evidenciada a inexistência de arrendamento a custos controlados e a recusa de proprietários em arrendar casas a ciganos. Por fim, são apresentados alguns condicionalismos à intervenção seja pela dispersão de necessidades de realojamento no concelho dificultando a intervenção, seja pela manifestação de diferentes tipos de expectativas relativas ao habitat por parte da população cigana residente.

Outras redes sociais procuram resolver os problemas associados com as formas de ocupação do espaço através de acções de realojamento. São os casos de Loulé que enuncia a construção de seis habitações numa freguesia do concelho para realojar população cigana (Plano de Acção, 2004-2005) ${ }^{18}$, mas também de Santiago do Cacém que prevê a realização de respostas no âmbito da habitação social e a aquisição de equipamentos para melhoria das condições habitacionais de cinco famílias (Diagnóstico Social, 2003), de Avis que igualmente evidencia o realojamento (Diagnóstico Social, s/d), de Felgueiras que embora refira que o concelho "carece de um estudo aprofundado acerca da comunidade cigana", projecta a "construção de habitação social própria" para seis famílias residentes em barracas (Diagnóstico Social, 2004), de Pombal que prevê o realojamento de famílias num bairro social e a construção de um bairro só para população cigana (Pré-Diagnóstico, Maio 2004) ${ }^{19}$. Entre estas propostas prevê-se no caso de um concelho, a eleição de dois representantes da comunidade cigana para participarem no processo de intervenção habitacional (PDS, 2005-2008; PA, 2005-2006).

\footnotetext{
${ }^{17} \mathrm{Na}$ sequência de um contacto estabelecido com esta rede social fomos informados que não estavam previstas intervenções habitacionais especificamente dirigidas à etnia cigana, acrescentando que também não foram desencadeadas outras ${ }^{\circ}$ acções a este nível.

$18 \mathrm{O}$ projecto previsto pela rede social de Loulé foi concretizado e é fácil encontrar referências à intervenção realizada. Por um lado, o ex- Instituto Nacional de Habitação engloba-o nas candidaturas ao prémio de 2006. Por outro lado, António Baptista Coelho salienta "o grande interesse que tem a continuidade de experiências deste tipo, em que se tenta, na prática, o desenvolvimento de soluções tipológicas que sirvam, simultaneamente, modos de vida específicos e a manutenção de uma imagem urbana digna e atraente; e anota-se a importância que terá o acompanhamento da ocupação destas casas de forma a ajuizar da sua adequação" (http://infohabitar.blogspot.com).

19 Dada a ausência de resposta ao pedido de esclarecimento, soubemos pelo GACI que houve um processo de realojamento tal como estava previsto no pré-diagnóstico em que para além de se tratar de um bairro só para ciganos, a sua localização é periférica face às centralidades urbanas
} 
Alguns concelhos relatam as situações de realojamento já realizadas nos últimos anos, sendo raros os casos em que são explicitadas as características do processo de realojamento e inexistentes as avaliações sobre a situação actual. Os concelhos de Elvas e Santo Tirso são dois concelhos que se destacam dos restantes por identificarem, ainda que de forma sucinta, as acções complementares ao realojamento, explicitando-se no primeiro caso os impactes negativos da falta de continuidade de um Projecto de Luta Contra a Pobreza iniciado em 1999 e finalizado em 2002.

Os exemplos aqui referidos são apenas algumas das situações de realojamento realizadas em Portugal, pois o Programa Especial de Realojamento, iniciado em 1993, com o objectivo de eliminar os bairros de barracas e transferir as suas populações para habitações camarárias, não dispõe de dados sobre o número de famílias ciganas que terão sido abrangidas, nem existem estudos de avaliação deste processo de realojamento.

A Gebalis, empresa municipal que gere os bairros municipais do concelho de Lisboa encontra-se a desenvolver um estudo de identificação e caracterização das famílias ciganas residentes nestes bairros. Actualmente, só estão disponíveis os dados relativos à zona de Lisboa Ocidental ${ }^{20}$ e constata-se que o maior número de realojamentos de famílias ciganas se deu em 1975 e em 1997, bem como no período compreendido entre 2001 e 2004. Existe uma discrepância entre a elevada visibilidade social das famílias ciganas nos bairros e a sua real expressão numérica ${ }^{21}$, não se registando homogeneidade na distribuição de agregados familiares pelos bairros municipais, nem a grandes deslocações, já que mais de metade dos realojamentos ocorreram no espaço da mesma freguesia ou na freguesia limítrofe (Antunes et al., 2007).

Com a sistematização desta informação pensamos ter contribuído para uma aproximação à dimensão do fenómeno de precariedade habitacional entre a população cigana, sinalizando-se algumas das áreas geográficas "mais sensíveis", onde seria necessário desencadear estratégias de intervenção de acordo com as especificidades das famílias e dos territórios. Alguns estudos têm constatado que as políticas de habitação e de acolhimento da população itinerante em meio urbano devem evitar situações padronizadas, optando por uma pluralidade de soluções, capaz de preservar a autonomia e a especificidade das famílias ciganas, pois os lugares de residência devem responder a necessidades diversas em função das estratégias de inserção ${ }^{22}$. Como refere Humeau, a possibilidade de encontrar uma diversidade de situações passa também por identificar as necessidades quantitativas e qualitativas e a variação de escalas geográficas de detecção de necessidades, sempre no pressuposto de que se faça a devida correspondência entre as lógicas territoriais das famílias e as formas de organização dos poderes locais (Humeau, 1997:7). Lacroix alerta também para o facto de que é a relação com o(s) lugar(es) que deveria servir de base aos diagnósticos que presidem à realização de áreas de acolhimento ou de projectos de habitação e não a relação com a mobilidade. É a diversidade de ligação ao local que conduz à diversificação necessária de oferta em matéria de estadia ou habitat (Lacroix, 2004:102).

Ao longo desta exposição são perceptíveis as limitações que os dados expostos ainda apresentam, nomeadamente pela inexistência de informação para áreas do país com grande concentração de população cigana; pela impossibilidade de uma análise diacrónica que permita perceber a evolução da situação habitacional e o impacte das políticas de habitação dos últimos tempos; pelo fraco aprofundamento das razões que justificam a persistência das situações de precariedade habitacional. É precisamente sobre estas razões que nos iremos debruçar de seguida. No entanto, a análise que se apresenta é ainda apenas um dos lados desta questão, pois iremos centrar-nos, exclusivamente, nos factores exógenos às comunidades ciganas que tendem a justificar aquelas situações.

\footnotetext{
${ }^{20}$ Que correspondem a 19 bairros, onde residem 428 agregados constituídos por 1878 indivíduos, correspondendo a 3,9\% do total dos agregados e $4,9 \%$ da totalidade da população.

${ }^{21} \mathrm{Na}$ zona ocidental de Lisboa os bairros com maior concentração de famílias são a Ameixoeira, onde os 616 ciganos representam $17,4 \%$ e o Casalinho da Ajuda com 199 ciganos a representarem 16,5\% face à população total.

${ }^{22}$ Ver entre outros Humeau, 1995, 1997; Kendall, 1997; Provot, 1985, 1998, 2004; Robert, 2000; Gilles, 2001; Aubin, 2003; Assier-Andrieu et al., 2003; Niner, 2004; Drobenko, 2004.
} 


\section{A Persistência das Situações de Pre- cariedade Habitacional: Os Factores Exógenos à População Cigana}

$\mathrm{O}$ acesso a condições adequadas de habitação assume-se como um dos pilares-chave dos processos de inclusão social, na medida em que facilita o acesso a outros recursos, serviços e direitos fundamentais. De acordo com Artigo 65. ${ }^{\circ}$ (Habitação e urbanismo) da Constituição da República Portuguesa "Todos têm direito, para si e para a sua família, a uma habitação de dimensão adequada, em condições de higiene e conforto e que preserve a intimidade pessoal e a privacidade familiar". Para assegurar este direito o Estado deverá: a) programar e executar uma política de habitação inserida em planos de ordenamento geral do território e apoiada em planos de urbanização que garantam a existência de uma rede adequada de transportes e de equipamento social; b) promover, em colaboração com as regiões autónomas e com as autarquias locais, a construção de habitações económicas e sociais; c) estimular a construção privada, com subordinação ao interesse geral, e o acesso à habitação própria ou arrendada; d) incentivar e apoiar as iniciativas das comunidades locais e das populações, tendentes a resolver os respectivos problemas habitacionais e a fomentar a criação de cooperativas de habitação e a autoconstrução; e) adoptar uma política tendente a estabelecer um sistema de renda compatível com o rendimento familiar e de acesso à habitação própria. (Art. ${ }^{\circ}$ $65 .^{\circ},{ }^{\circ}{ }^{\circ} 1,2,3$ da Constituição da República Portuguesa, 1997).

Apesar destes direitos e deveres estabelecidos constitucionalmente, o diagnóstico geral sobre a habitação em Portugal aponta, entre outros aspectos, para a persistência de carências habitacionais; a existência de um parque habitacional com graves problemas de requalificação e revitalização; a presença de novas necessidades de habitação, com perfis diversificados de procura social (tipo de famílias, estilos de vida...); especialização da oferta de habitação para "venda", em detrimento de soluções alternativas e diversificadas; a falta de coerência, eficácia e eficiência na afectação de recursos públicos no domínio da produção e gestão da habitação (Freitas, 2007).
Se anteriormente constatámos que persistem carências habitacionais para cerca de 7000 portugueses ciganos interessa agora explorar alguns dos factores que tendem a explicar a manutenção deste problema, nomeadamente os principais obstáculos que têm condicionado o acesso a oportunidades de inclusão social por via da habitação. Por um lado, encontram-se discursos técnica e cientificamente pouco fundamentados para justificar a situação habitacional precária e a inacção política, onde o nomadismo aparece como denominador comum, seja enfatizando-se a presença de ciganos itinerantes, seja admitindo-se a sua inexistência. Por outro lado, constata-se a existência de estratégias públicas de âmbito local para a não fixação e para a mobilidade forçada de algumas famílias ciganas. Por fim, assiste-se à inexistência de tradução dos problemas e necessidades sentidos localmente nos sucessivos Planos Nacionais de Acção para a Inclusão e em medidas de política de habitação que pudessem colmatar alguns dos problemas identificados.

Factores discursivos técnica e cientificamente pouco fundamentados para justificar a precariedade habitacional e a inacção política

"Eles são considerados nómadas, porque eles não são residentes; construíram aquelas barracas sem autorização e quando a GNR lá vai, eles vão embora. Portanto eles não são residentes." (Entrevista a assistente social num serviço local da Segurança Social, 2006.)

A mobilidade espacial dos ciganos associada às suas formas específicas de apropriação do espaço é, usualmente, denominada de nomadismo e itinerância. Estas designações tendem a ser demasiado amplas para traduzir a especificidade da sua relação com a itinerância ou com a sedentariedade, uma vez que esta relação está muito ancorada nas condições económicas, nas relações familiares, na pressão do exterior, entre outros aspectos (Provot, 1995). Por outro lado, as tentativas de classificação do grau de itinerância - "famílias sedentarizadas", "itinerância regular ou fraca", "semi-itinerante" - apresentam-se como demasiado redutoras ou pouco fidedignas da sua organização social e da diversidade de modos de vida que se podem encontrar (Provot, 1995, Humeau, 1995). 
Parece, pois, existir uma diversidade de situações familiares que se reflecte numa relação específica com o território e o habitat nem sempre de apreensão imediata para um observador externo. O não aprofundamento desta relação acaba por se reflectir numa adesão acrítica ao pressuposto de que muitas famílias ciganas não têm acesso a uma casa porque optaram por um modo de vida itinerante, ignorando-se assim as suas carências ao nível de uma habitação condigna. Este pressuposto, assente em atributos de uma identidade prescrita, está presente em vários dos discursos, escutados ao longo do trabalho de terreno, de um conjunto de entidades com responsabilidade em termos da inclusão social, tais como "eles são assim [nómadas] porque é da cultura deles", "estarmos a pô-los em casas é ir contra a cultura deles", ou "eles gostam de ser livres e não de estar fechados, numa casa", ou ainda "porque eles também têm vantagens em viverem assim, de um lado para o outro".

O discurso científico sobre esta matéria também não tem sido esclarecedor. Reforça-se a ideia da existência de itinerantes assumindo-se posições como "a itinerância é o elemento fundamental da organização cigana", ou "a coesão familiar é possível graças à itinerância", ou ainda "a viagem é fundamental para o sentido identitário cigano"23. Fazendo uma revisão da literatura publicada na revista Études Tsiganes entre 1986 e 1998 a propósito da identidade das populações nómadas, Provot constata que os conceitos de sedentariedade e nomadismo permanecem vagos, pois apesar de representarem elementos importantes da vida dos grupos ciganos, não evocam a sua vida económica e nada dizem sobre a identidade étnica ou cultural. Como refere o autor, embora os ciganos tenham aparecido na Europa como itinerantes, eles não a reproduzem sempre da mesma maneira. A itinerância é uma herança histórica, mas não um pilar essencial do seu edifício social (Provot, 2004).

Segundo Lacroix, as representações sociais sobre o nomadismo construíram uma oposição entre nomadismo e território. O nomadismo assemelhava-se mais a errância - viajar sem qualquer finalidade - do que a itinerância, não existindo assim nenhuma razão particular dos nómadas esta- rem em determinado lugar. Ser nómada era não ter nenhuma ligação ao lugar e aí estar de forma ilegítima (Lacroix, 2004). É possível assim interrogar-nos se a ligação a um determinado território se coloca tanto para os ciganos como para qualquer outro tipo de população, qual é o sentido da recusa de que são alvo e que os constitui ilegítimos em determinado do lugar?

Mesmo que a permanência de determinadas famílias ciganas em território concelhio assuma um carácter relativamente duradouro e exista um desejo de aí fixarem residência, constata-se que o acesso àqueles direitos deve ser assegurado algures, traduzindo aquilo que em linguagem anglo-saxónica se apelida de sindromas NIMBY (not in my back yard) e NOTE (not over there either). Ascher considera estes fenómenos como um traço específico da modernidade, um reflexo do individualismo levado ao extremo, e que pode constituir uma ameaça à coesão social. Estes fenómenos de rejeição são encarados como défices de cidadania, fundados na prevalência dos direitos subjectivos e individuais (corporativos ou localistas) sobre os direitos e necessidades da colectividade. E é perante tal contexto sociopolítico que se favorece a emergência de comunitarismo inscritos nas lógicas de exclusão e rejeição (Ascher, 1995: 102-103). De certa forma, é como se a mobilidade espacial - inabitável e suspeita - traduzisse uma recusa implícita de aceitação das regras do jogo. A sedentarização aparece como requisito fundamental, mas em territórios de outros, já que "os nómadas, tornados residentes, escapam ao efémero" (Provot, 1987).

A aparente "força" dos argumentos apresentados anteriormente ou a sua falta de fundamento, escamoteando as reais carências habitacionais, tende a desencadear duas posições ou reacções distintas quer em determinadas entidades locais, quer em determinados técnicos ou cientistas sociais, mas também elas redutoras da compreensão da mobilidade da população cigana.

Por um lado, procurando-se ignorar ou invisibilizar esta realidade, várias entidades a nível local tendem a ver nas estratégias de sedentarização uma transição ainda inacabada do nomadismo, logo não sendo objecto de preocupa-

\footnotetext{
${ }^{23}$ É possível encontrar citações desta natureza em várias publicações académicas nacionais e internacionais (ver entre outras, Xufre, 2004; Janodet et al., 1992; Nunes, 1981, Leite de Vasconcellos, 1956).
} 
ção do poder local. Ou seja, parte-se do pressuposto de que qualquer estratégia desencadeada pelos ciganos com vista à fixação traduz uma ocupação abusiva do espaço, uma forma de beneficiar de determinadas medidas de protecção social ou de acesso a determinados serviços, não se procurando as relações que mantêm com os lugares em que se instalam.

Por outro lado, procurando-se contrariar a tendência de desresponsabilização dos poderes públicos ou evidenciar as atitudes persecutórias que explicam um nomadismo forçado, recusa-se o aprofundamento da problemática da mobilidade, chegando-se ao ponto de recusar a existência de itinerância entre a população cigana. No Relatório da Obra Nacional da Pastoral dos Ciganos pode ler-se: "não existem ciganos itinerantes em Portugal ao contrário do que afirmam as câmaras municipais e as estruturas sociais, pois o facto de não serem recenseados faz com que se afirme que se desconhece a existência de acampamentos permanentes de ciganos" (ONPC, 2000:31).

Qualquer um dos argumentos apresentados ao longo desta secção acaba por ter um duplo efeito. Por um lado, não se aprofundam os sentidos que as sumem determinados modos de vida, como se o Cigano - entidade vista como homogénea - tivesse de se conformar a determinado modo de vida onde nem ele próprio muitas vezes se reconhece. Por outro, não se aborda a questão no plano das políticas da identidade étnica, fomentando-se o ciclo de exclusão a que os portugueses ciganos têm sido sujeitos.

\section{Estratégias públicas de âmbito local para a não fixação e para a mobilidade forçada}

“Com os nómadas? Aí... como nós não temos lidação com eles (...) o melhor era contactarem as juntas de freguesia ou a GNR, que a GNR conhece-os porque anda sempre atrás deles." (Entrevista colectiva realizada a técnicas de uma câmara municipal do Alentejo, 2006.)

Constatámos como as representações sobre o nomadismo tendem a condicionar a implementação de práticas que visem a melhoria das condições habitacionais da população cigana, interessa agora identificar as estratégias que são desencadeadas para impedir a sua fixação em determinada localidade. Convém distinguir entre a população ciganas, as famílias que têm uma habitação móvel, como a tenda ou o carro, daquelas que ocuparam casas ou infra-estruturas devolutas ou construíram casas abarracadas em terrenos públicos, de privados ou dos próprios, aí permanecendo com um carácter duradouro.

No primeiro caso, importa referir a inexistência em Portugal, ao contrário do que acontece noutros países europeus, de dispositivos normativos que regulem o estacionamento de populações itinerantes. O recurso ao DL 310/2002 de 18 de Dezembro foi uma das formas encontradas para lidar com esta situação, embora este englobe sobretudo actividades, como a de guarda-nocturno, vendedor-ambulante de lotarias, arrumador de automóveis, acampamentos ocasionais, realização de fogueiras. Apesar de não existir nenhum diploma legal que estipule o tempo máximo de permanência em determinada localidade por parte da população itinerante, parece existir uma ideia generalizada de que os ciganos não podem exceder as 24 ou 48 horas no mesmo lugar.

Constata-se, assim, que a liberdade de circular no domínio público é temporária, pois repousa na existência de uma pressuposta estabilidade e na posse de um habitat fixo. Quando determinadas populações estão desprovidas destas condições, acabam por ficar condenadas à errância, pois as regulamentações de urbanismo e de estadia proíbem que seja feito do domínio público um uso privativo contínuo (Provot, 1998).

Mesmo as famílias ciganas que procuram instalar-se em localidades onde sentem pertencer, vivenciam uma inserção territorial muito precária fruto de perseguição, expulsões e agressões continuadas por parte das forças policiais ${ }^{24}$. Estas situações ocorrem por estarem a ocupar terrenos públicos ou privados, não se registando no país, à excepção do concelho de Vila Viçosa, áreas

\footnotetext{
${ }^{24}$ Os relatos que escutámos incluem: agressões físicas graves, incluindo a portadores de deficiência física, a destruição de carroças e outros meios de locomoção, agressões aos animais que são força de tracção, de corte dos panos com que se abrigam da chuva e do frio, apropriação do material que transportam consigo. Para um maior aprofundamento cf. Correia (2007).
} 


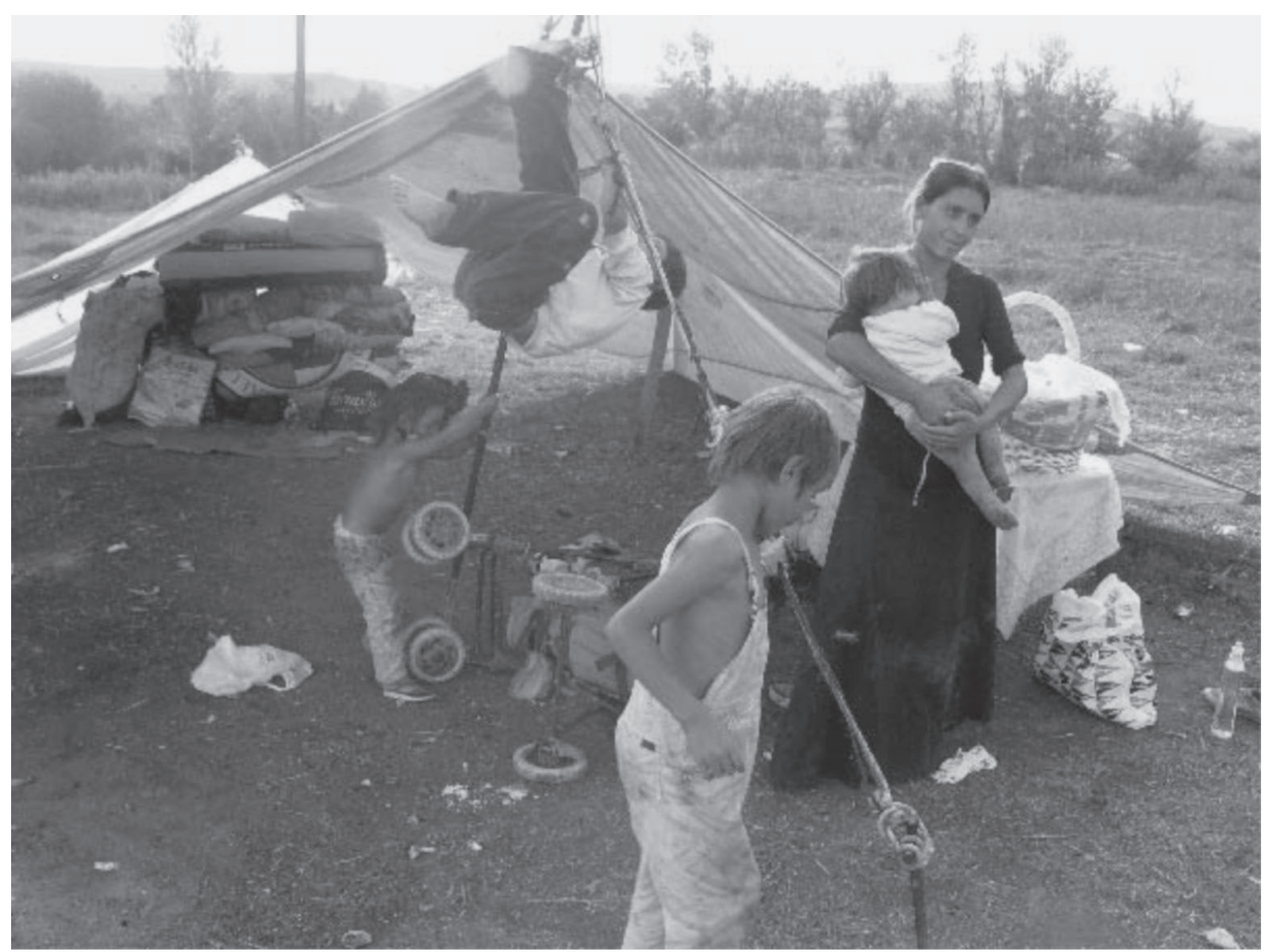

Fonte: André Clareza Correia

de acolhimento para a população sem residência fixa ${ }^{25}$.

De acordo com os dados recolhidos através dos questionários às câmaras municipais e à GNR verifica-se que perante a presença de ciganos em locais públicos durante mais de 48 horas, a força policial da GNR tenta sobretudo impedir essa presença $(43,7 \%)$, mas também proceder à vigilância das famílias que permanecem em determinada localidade $(27,6 \%)$. Esse controlo das famílias ciganas assenta na obtenção de informações várias, nomeadamente a identificação dos presentes, as actividades a que se dedicam, os motivos que os levam a estar em determinado concelho, qual a sua origem bem como o seu destino. Também as câmaras municipais tendem para uma actuação semelhante, uma vez que metade dos municípios: contacta os agentes da autoridade $(31,8 \%)$, os próprios serviços municipais de fiscalização informam os ciganos para desocuparem os locais $(12,1 \%)$ e em $6,1 \%$ os ciganos são "avisados"/"intimidados" a abandonar o local por uma entidade não discriminada (cf. Quadro 3).

\footnotetext{
${ }_{25}$ De acordo com o levantamento efectuado junto das câmaras municipais (CTI 1, 2005) apenas 14 equacionaram a possibilidade de construir um local específico para acolher populações itinerantes, foram eles: Beja, Cascais, Coimbra, Elvas, Évora, Ferreira do Alentejo, Monforte, Paços de Ferreira, Reguengos de Monsaraz, Santarém, Vidigueira, Vila Nova de Gaia, Vila Real de Santo António e Vila Viçosa. Apenas Vila Viçosa acabou por concretizar a ideia, no seguimento de uma reunião camarária realizada em 2000 e concretizando-se num terreno situado a sudoeste do Parque Industrial. O projecto caracteriza-se pela delimitação da área e pela instalação de um ponto de água. A principal razão apontada para a sua concretização prendeu-se com a necessidade de "aumentar a segurança rodoviária", uma vez que os ciganos que se deslocavam ao concelho (2 ou 3 famílias) acampavam junto à estrada que liga Vila Viçosa ao Alandroal, na altura de três feiras anuais. (Cf. para maior aprofundamento Duarte et al. 2005a).
} 
Constata-se, assim, que a maioria dos postos da GNR e das Câmaras Municipais tende para uma actuação impeditiva e de vigilância face à presença dos ciganos por um período superior a dois dias, por se associar a esta população determinadas imagens negativas. Estamos, pois, perante uma actuação herdada do passado ${ }^{26}$, mas desajustada face ao quadro legal em vigor.

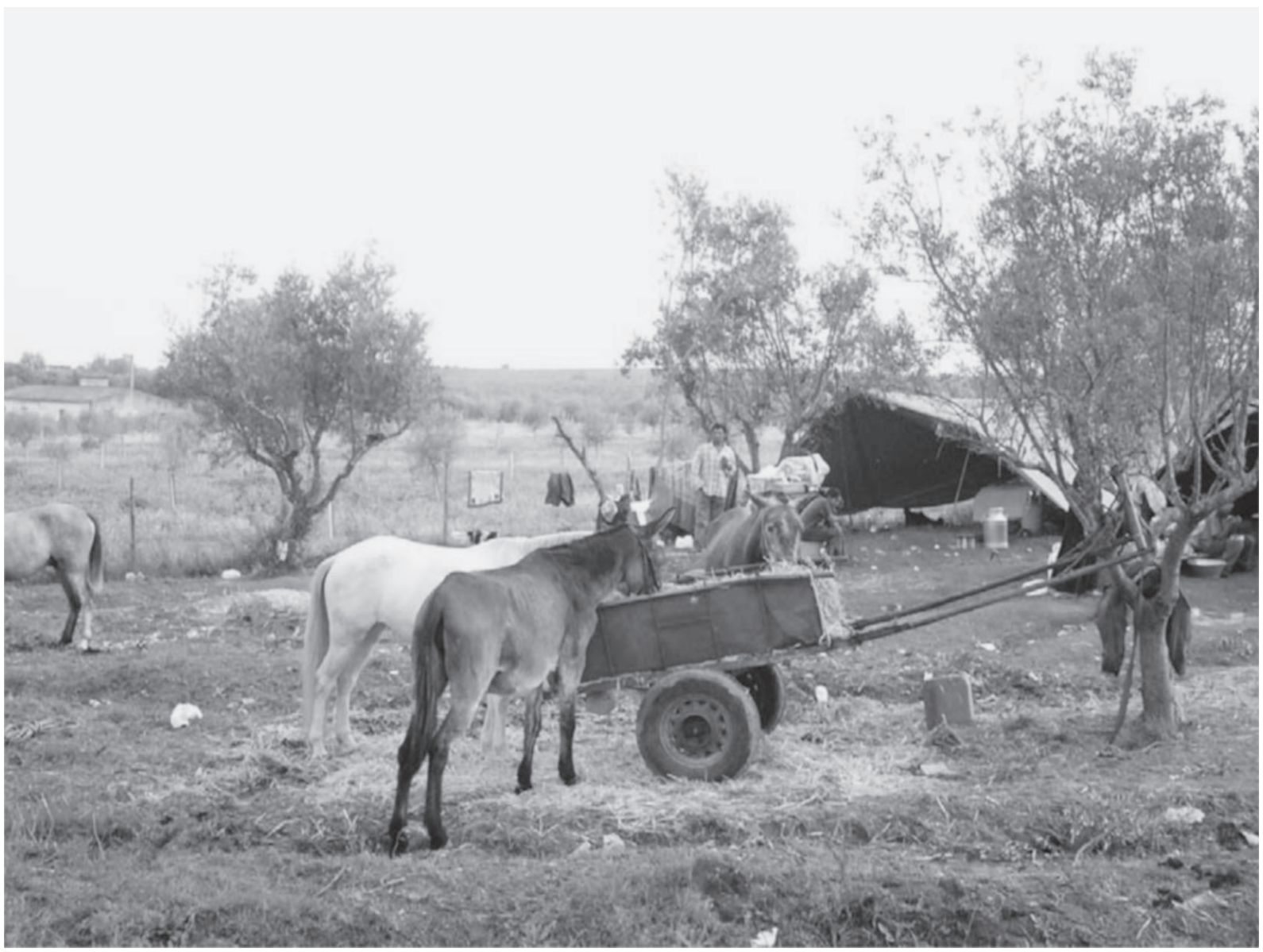

Fonte: André Clareza Correia

\footnotetext{
${ }^{26}$ Recuando apenas até 1920 encontra-se o Regulamento para o Serviço Rural da Guarda Nacional Republicana (Decreto n. ${ }^{\circ} 6950$, de 26 de Setembro de 1920.). As normas constantes dos artigos $182 .^{\circ}$ a $185 .^{\circ}$ apelam à necessidade de se exercer "uma severa vigilância sobre os ciganos, observando-os constantemente nos seus movimentos com o fim de prevenirem e reprimirem os seus frequentes actos de pilhagem" $\left(\right.$ art. $^{\circ} 182 .^{\circ}$ ), atribuindo-se à identidade cigana o estatuto de "duvidosa", o que justificaria a sua detenção em casos de transgressão ou contravenção "desde que não depositem em mão de pessoa competente a importância da multa ou não apresentem fiadores idóneos" (art. $\left.{ }^{\circ} 185 .{ }^{\circ}\right)$. Em 1980, o Conselho da Revolução declarou a inconstitucionalidade de todas estas normas por infringirem o disposto no n. 2 do artigo $13 .^{\circ}$ da Constituição da República Portuguesa. Em 1985, aquela "especial vigilância" deixa de ser atribuída explicitamente a ciganos. Vê-se então surgir no novo Regulamento Geral do Serviço da Guarda Nacional Republicana, na Parte III - Serviço Territorial, a Secção XVII destinada à vigilância sobre nómadas, mendigos e vadios. Prostituição (Portaria 722/85 de 25 de Setembro DR, DR, $1 .^{\mathrm{a}}$ Série, n. ${ }^{\circ} 221$, de 25 de Setembro de 1985, p. 48). O Procurador-Geral da República veio entretanto requerer que o Tribunal Constitucional declarasse a inconstitucionalidade das normas de um dos artigos por considerar que se estava a visar os ciganos, violando-se assim o princípio constitucional da proibição de diferenciações ilegítimas. No entanto, a maioria do TC entendeu que não se registava qualquer violação do princípio da igualdade, pois na categoria de nómadas para além dos ciganos estavam incluídos outros grupos de pessoas.
} 
Quadro 3: Medidas adoptadas perante a permanência de ciganos em locais públicos durante mais de 48 horas por parte da GNR e das Câmaras Municipais

\begin{tabular}{|c|c|c|c|}
\hline \multicolumn{2}{|l|}{ GNR } & \multicolumn{2}{|l|}{ Câmaras Municipais } \\
\hline Impedida a sua permanência & $43,7 \%$ & $\begin{array}{l}\text { Contactar agentes da autoridade para } \\
\text { desocuparem local }\end{array}$ & $31,8 \%$ \\
\hline Vigilância & $27,6 \%$ & $\begin{array}{l}\text { Serviços municipais informam ciganos } \mathrm{p} / \\
\text { desocuparem local }\end{array}$ & $12,1 \%$ \\
\hline Solicitar informações & $6,0 \%$ & $\begin{array}{l}\text { "Avisados"/,"Intimidados" a abandonar } \\
\text { local por entidade não discriminada }\end{array}$ & $6,1 \%$ \\
\hline $\begin{array}{l}\text { Advertência da ilegalidade/ } \\
\text { /encaminhamento para a Câmara } \\
\text { Municipal }\end{array}$ & $5,5 \%$ & & \\
\hline $\begin{array}{l}\text { A curta permanência não justifica } \\
\text { intervenção }\end{array}$ & $7,0 \%$ & $\begin{array}{l}\text { A curta permanência não justifica } \\
\text { intervenção }\end{array}$ & $15,2 \%$ \\
\hline Outras & $5,5 \%$ & Outras & $10,6 \%$ \\
\hline Nenhuma & $4,5 \%$ & Nenhuma & $24,2 \%$ \\
\hline
\end{tabular}

Fonte: Questionário CTI 1, 2005; CTI 2, CET, 2006.

No caso das famílias ciganas que ocuparam casas ou infra-estruturas devolutas ou construíram casas abarracadas em terrenos públicos, de privados ou dos próprios, aí permanecendo com um carácter duradouro parece existir uma vontade deliberada de não se desencadearem os esforços necessários na implementação de projectos de inclusão social, utilizando-se frequentemente poderes discricionários para bloquear as iniciativas que visem a melhoria das condições de vida da população cigana. Por detrás desta estratégia parecem mais uma vez coexistir os fenómenos nimby associados à pressão que é exercida aos poderes locais por parte da opinião pública, nomeadamente através do reforço da ilegitimidade da sua presença, da ausência de uma coexistência inter-étnica pacífica, da falta de salubridade e higiene pública dos espaços ocupados. Preocupações de carácter eleitoralista, aliadas à escassez de recursos a nível local para resolver problemas de diferente natureza que se colocam à generalidade das populações desfavorecidas dos concelhos, e perante o receio de que qualquer intervenção poderia aumentar a dimensão da população cigana, tendem a colocar em segundo plano qualquer acção que vise a melhoria das condições habitacionais dos portugueses ciganos, ocultando-se ou subestimando-se as carências a este nível.
É, pois, comum, encontrar várias estratégias que tendem a perpetuar a precariedade das situações habitacionais, tais como:

- não se possibilita o acesso à água, à electricidade ou ao saneamento básico, sob o pretexto de que seria um incentivo para o aumento da fixação de outras famílias;

- não se disponibilizam as infra-estruturas necessárias aos "acampamentos" que se encontrarem em zonas ilegais, terrenos agrícolas ou reservas naturais, pelo estatuto dos terrenos ocupados, não se encontrando áreas alternativas de fixação;

- não se faz deliberadamente a recolha do lixo à espera que a situação se torne insustentável e os ciganos abandonem o concelho;

- adia-se a procura da localização possível no concelho para determinadas famílias se poderem instalar, inviabilizando-se a apresentação de candidaturas a medidas e projectos de intervenção social;

- não se reconhece o estatuto de residente, impedindo-se o acesso a determinadas serviços (ex.: conta bancária); 


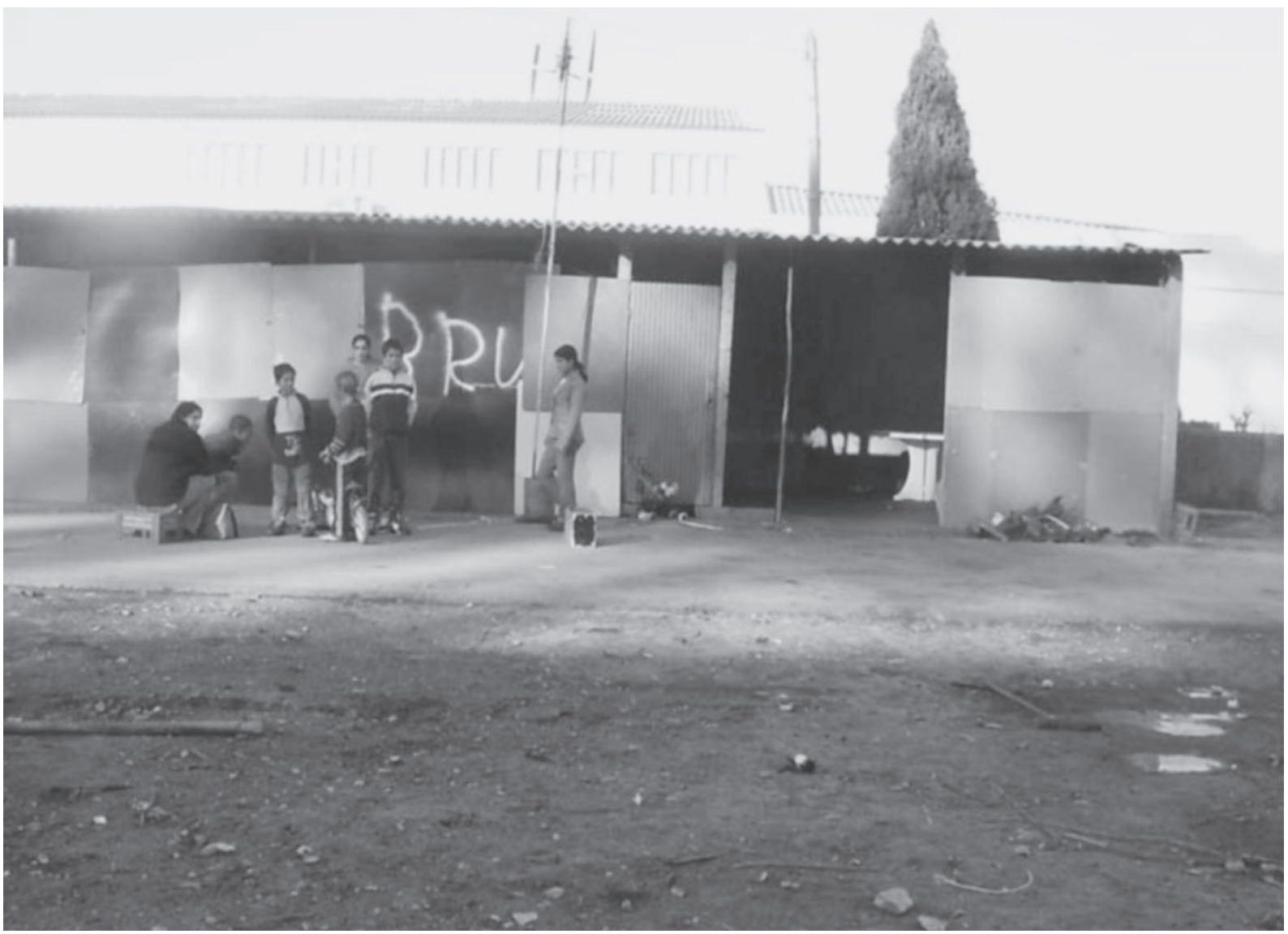

Fonte: Alexandra Castro

Apresentámos aqui os casos onde são marcantes as estratégias desenvolvidas para perpetuar a mobilidade forçada e ignorar a fixação em determinado território. No entanto, como vimos anteriormente estas estratégias não são extensíveis a todos os concelhos país. Seria, pois, fundamental dar visibilidade às intervenções realizadas e avaliar o impacte das medidas adoptadas nos processos de inclusão social, para que as boas práticas possam ser disseminadas e incorporadas pelos territórios mais resistentes à mudança. No entanto, como veremos de seguir a necessidade desta mudança não se coloca apenas no plano local, mas também ao nível das orientações nacionais.

\section{A invisibilização política da questão habitacional dos ciganos}

Os estudos anteriormente referidos, bem como as orientações internacionais e nacionais em ma- téria de habitação parecem ainda não ter tido o impacte suficiente para a elaboração de uma estratégia nacional para a inclusão social desta população, onde a problemática da habitação mereça um lugar de destaque.

Em 2005, o Conselho da Europa aprovou uma recomendação visando a melhoria das condições habitacionais dos ciganos, independentemente do seu grau de mobilidade e das suas aspirações em termos de alojamento. A recomendação, dirigida aos então 46 Estados-membros, elege a habitação como uma das prioridades para a integração social dos ciganos nos próximos dez anos, a par da educação, do emprego e da saúde. No entanto, em Outubro de 2007, cinco organizações de direitos humanos ${ }^{27}$ fazem um apelo ao comissário do Conselho da Europa para os Direitos Humanos e ao Responsável das Nações Unidas para o direito a uma habitação adequada, enfatizando o aumento das expulsões forçadas e censurando a impunida-

\footnotetext{
${ }^{27}$ COHRE (Centre for Housing Rights and Evictions), GHM (The Greek Helsinki Monitor), MSF (The Milan Simecka Foundation), OsservAzione (The Centre for Action Research against Roma and Sinti Discrimination) e ERRC (European Roma Rigts Centre). Esta declaração pode ser consultada em http://www.eurocharity.org/en/article.php?article_id=2150.
} 
de de entidades públicas e outras na violação das leis nacionais e internacionais dos direitos humanos. E é assim que ainda em Outubro aqueles responsáveis vêm novamente apelar a esforços concertados a nível nacional, local e transnacional para terminar com a crise habitacional dos ciganos, salientando sete prioridades já contidas nas recomendações de $2005^{28}$.

No sentido de dar maior visibilidade àquela recomendação, optou-se pela sua tradução quase integral que se encontra sistematizada nos quadros seguintes. As cinquenta e duas proposições enunciadas estão organizadas em sete domínios. Os Princípios Gerais estabelecem as orientações para a intervenção na área da habitação, nomeadamente a necessidade de políticas não discriminatórias, integradas que promovam e protejam o direito à habitação e o seu acesso a custos controlados, que garantam a liberdade de escolha de modos de vida, que previnam a exclusão e a criação de guetos, que potenciem a participação dos ciganos em todas as fases do processo, mas também o trabalho em rede a diferentes níveis territoriais com incentivos às entidades locais para cumprirem as suas obrigações na área da habitação. O Quadro Legal prevê o desenvolvimento de dispositivos legais, a sua implementação e monitorização, bem como o incremento do apoio jurídico a ciganos que vêm negados o direito à habitação, nomeadamente através da garantia de condições às ONG que possam assegurar esta função. A Prevenção e o Combate à Discriminação pretende garantir o conteúdo não discriminatório das disposições legais para que o direito à habitação e à igualdade de oportunidades entre homens e mulheres seja assegurado, providenciando-se sanções efectivas para o seu não cumprimento. A Protecção e Promoção da Habitação Existente visa assegurar a protecção contra expulsões ilegítimas, procurando resolver o estatuto ilegal das áreas de fixação e garantir o alojamento alternativo adequado. O Enquadramento das Políticas de Habitação alerta para a necessidade de pensar as políticas em função da diversidade de situações a nível nacional, regional e local e das necessidades específicas e diversas das comunidades ciganas, o que exige a participação dos ciganos e o envolvimento das entidades locais e regionais no cumprimento das suas obrigações. O Financiamento da Habitação vai ao encontro da garantia da diversidade de fontes de financiamento para se cumprirem objectivos mensuravelmente estabelecidos, cabendo a sua gestão às redes de parceiros, devendo ser aplicados de forma integrada e sustentável e pressupondo facilidades de acesso a financiamento para aquisição de habitação. Os Padrões Habitacionais englobam todos os parâmetros considerados adequados pela Agenda do Habitat das Nações Unidas (Nações Unidas Habitat, 2003: 22), enfatizando-se recomendações ao nível da localização das habitações, da oferta de serviços e equipamentos, dos padrões de construção e da adaptabilidade e expansão do edificado.

Já em 2004, um estudo desenvolvido por um consórcio e financiado pela Comissão Europeia apontava recomendações ao nível da inclusão social, referindo-se que os ciganos deveriam ser claramente citados como grupo prioritário beneficiando de financiamento anual no quadro da política de inclusão social global de cada Estado-membro. Os Planos de acção nacionais deveriam incluir medidas específicas para os ciganos e viajantes em todas as rubricas dos sectores e os governos deveriam deixar de intervir sobre os ciganos através de uma conjunto fragmentado de projectos individuais (ERRC, et al. 2004: 60). Adianta-se, ainda, que a União Europeia deveria explicitamente identificar os ciganos nas políticas existentes de inclusão social e não pressupor que os ciganos serão cobertos por tais políticas. Estas políticas deveriam ser eficazmente dirigidas por um órgão dotado de influência e autoridade suficiente para garantir que os departamentos da UE, os governos dos Estados membros e outras partes tomem medidas decisivas relativamente à integração dos ciganos (idem: 54).

A nível nacional desde 2001 que também se apela à diversificação de medidas em função das especificidades dos contextos locais e familiares. Não é demais relembrar que o estudo desenvolvido pelo SOS Racismo, no âmbito do Grupo de Trabalho para a Igualdade e Inserção dos Ciganos do Alto Comissário para as Minorias Étnicas ${ }^{29}$, refere que "é necessário que a intervenção dirigida à in-

\footnotetext{
${ }^{28} \mathrm{http}$ //www.coe.int/t/commissioner/Activities/news2007/071023romahousingrights en.asp.

${ }^{29}$ Este Grupo foi constituído em 1996 pela Resolução do Conselho de Ministros n. ${ }^{\circ} 1 \overline{7} 5 / 96$ de 19 Outubro e desde o XV Governo Constitucional (2002) que se encontra com a actividade suspensa. Segundo o GACI do ACIDI em Janeiro de 2008 entrará novamente no activo.
} 
serção das comunidades ciganas caminhe no sentido de uma maior intensificação e diversificação das medidas, exigindo-se também um planeamento mais ambicioso das actividades, integrando os vários factores determinantes da exclusão e discriminação destes grupos, levando, naturalmente, em consideração as diversidades vividas localmente" (Albuquerque, 2001: 63). No âmbito das actividades da Rede Europeia Satipen / Grupo de Trabalho Sina realizou-se, em 2002, um encontro sobre habitação e comunidades ciganas ${ }^{30}$, importando aqui salientar as principais recomendações alcançadas: 1) realojar e procurar soluções mais adaptadas; 2) avaliar os processos de realojamento e modificar os pontos menos positivos; 3) promover o conhecimento entre ciganos e não ciganos e estratégias de mediação no sentido de atenuar as situações de conflito; 4) criar respostas diferenciadas, flexíveis e adaptadas à heterogeneidade da população cigana; 5) promover o conhecimento científico e rigoroso das comunidades ciganas; 6) auscultar a opinião das populações, activar a participação e promover o envolvimento das comunidades ciganas na resolução dos problemas que lhes dizem directamente respeito; 7) incentivar a utilização de recursos de mediação - Associativismo e mediação; 8) desenvolver cada vez mais um trabalho de parceria e em rede; 9) proceder a uma atribuição rigorosa de benefícios sociais.

Uma investigação desenvolvida pelo European Roma Rights Centre (ERRC) e pela Númena-Centro de Investigação em Ciências Sociais procurou explorar o impacte dos Planos Nacionais de Acção para a Inclusão Social (PNAI) na República Checa, França e Portugal na capacidade dos ciganos acederem à segurança social, à habitação social, a pensões do Estado e serviços de saúde públicos ${ }^{31}$. Um dos problemas apontados aos
PNAI destes três países reside no "facto de conterem neles poucas ou nenhumas políticas concebidas especificamente para lidar com os aspectos relacionados com a exclusão social de grupos marginalizados tais como os ciganos" (ERCC/Númena, 2007: 14), mas também a "distância entre a política a nível nacional e local" que se traduz na dificuldade em traduzir os objectivos nacionais em objectivos locais a alcançar (idem:17-18).

Embora se continue a insistir na necessidade de um estudo a nível nacional que caracterize a realidade socioeconómica da população cigana ${ }^{32}$, tal como refere o Relatório de Actualização do PNAI 2005 - 2006, parece um ponto assente que:

"as comunidades ciganas continuam a ser um grupo minoritário, muito exposto a fenómenos de pobreza, exclusão e discriminação. De uma forma geral, vivem em condições precárias de habitação, com baixas qualificações escolares e profissionais e com dificuldade de aceder acesso à maioria dos bens e serviços de saúde, emprego, educação e formação. Sendo este um dos grupos mais afectados por fenómenos de pobreza e exclusão e contra o qual persistem muitos preconceitos e estereótipos, são escassas, pontuais e localizadas as medidas realizadas no âmbito destas comunidades, como comprova o insuficiente número de metas inscritas no PNAI." ${ }^{\text {33 }}$

Embora este relatório tenha constatado que as medidas são "escassas, pontuais e localizadas", o PNAI para 2006-2008 é totalmente omisso em termos de medidas e metas a alcançar com esta população, contrariando as orientações internacionais sobre esta matéria, mas também sendo alvo de críticas por parte do Fórum Não Governamental para a Inclusão Social (FNGIS) ${ }^{34}$.

\footnotetext{
${ }^{30}$ Este encontro realizou-se em Braga, a 10 de Dezembro de 2002, estando as conclusões e recomendações publicadas em Reapn (2003: 8-12)

31 O PNAI português refere-se ao período de 2003-2005.

32 De referir que o ACIME lançou um concurso em 2005 para a realização de um "Estudo sobre comunidades ciganas em Portugal" ao qual o Centro de Estudos Territoriais concorreu. Embora as propostas tenham sido avaliadas por um júri, os resultados do concurso nunca chegaram a ser divulgados.

33 Cf. http://www.pnai.pt/.

${ }^{34}$ Este Fórum nasce da resposta de diversas entidades não governamentais de âmbito nacional a um convite por parte da Coordenação do Plano Nacional de Acção para a Inclusão (PNAI), com a finalidade de concretizar, em parte, o $4^{\circ}$ Objectivo Comum do Processo Europeu de Inclusão Social - "Mobilizar o conjunto dos intervenientes". O processo da sua constituição decorreu entre Junho de 2004 e Fevereiro de 2006 , constituindo-se formalmente em Março de 2006. Conta actualmente com 24 entidades de carácter intersectorial e interinstitucional, e pretende funcionar como uma plataforma de interlocução com a Comissão Interministerial do PNAI. Através da emissão de pareceres, concepção de documentos e propostas alternativas que reflictam a opinião do sector não governamental, pretende contribuir para o acompanhamento e avaliação do PNAI em curso e para a construção de futuros Planos (http://foruminclusao.no.sapo.pt).
} 
A nível nacional o FNGIS aponta como sendo

"muito preocupante que no PNAI 2006-2008 se tenha optado por excluir dessa prioridade as Minorias Étnicas (...), e que, com esta opção não seja feita qualquer menção às Comunidades Ciganas, nem esteja prevista qualquer meta ou programa de intervenção com as mesmas. Tal situação significa um recuo face ao PNAI 2003-2005, o que não pode deixar de constituir uma fonte de preocupação (...). Como é também sabido, ainda e quando o acesso [aos direitos] está garantido, manifestações de racismo e discriminação (...) constituem um forte impedimento em relação à concretização dos mesmos. É por isso que, na nossa opinião, seria de extraordinária importância que tivessem sido estabelecidas metas e medidas no domínio do combate ao racismo e discriminação, particularmente em relação a grupos e comunidades onde tal fenómeno é um dos principais factores de exclusão social" (FNGIS, 2006:4).

Por contraponto à situação do PNAI português vigente, o PNAI espanhol para o mesmo período e na secção relativa à actuação a favor dos grupos mais vulneráveis estabelece oito objectivos para a população cigana, que pressupõem o envolvimento de diferentes ministérios na sua execução, nomeadamente:

1. Desenvolver projectos de intervenção social integrada para a prevenção da marginalização e inserção do povo cigano em colaboração com as Comunidades Autónomas;

2. Desenvolver acções relativas à igualdade de tratamento e de oportunidades, à formação e ao intercâmbio de informação e boas práticas sociais;

3. Desenvolver planos específicos para a população cigana por parte das Comunidades Autónomas;
4. Realizar um inquérito nacional sociodemográfico sobre a população cigana, bem como um estudo sobre as suas condições de saúde;

5. Elaborar um mapa sobre habitação e comunidade cigana em Espanha;

6. Desenvolver programas de inserção laboral e de inserção em colaboração com as ONG;

7. Constituir e desenvolver as funções do Conselho Estatal do Povo Cigano;

8. Criar o Instituto de Cultura Cigana para o desenvolvimento e a promoção da história, cultura e línguas ciganas.

Nenhum dos ministérios envolvidos na elaboração do PNAI português estabeleceu metas e medidas específicas para a população cigana. Parece ficar no "segredo dos deuses" o que poderá justificar a estratégia portuguesa de omissão da população cigana como grupo prioritário de intervenção. Será que a inexistência de recursos justifica uma omissão tão grande? E se o diagnóstico ainda é incipiente não terão os ministérios os recursos financeiros e humanos suficientes para desencadearem tal diagnóstico? Não terá a população cigana o mesmo direito a medidas de discriminação positiva como outros grupos igualmente vulneráveis a situações de pobreza e exclusão social? Será que é a hostilidade generalizada contra os ciganos que coloca entraves à elaboração de políticas dirigidas a esta população?

Se olharmos para as metas e medidas inscritas no PNAI 2006-2008, susceptíveis de resolver as situações de carência habitacional vivenciadas pelos ciganos, constatamos que as medidas que visam a promoção da melhoria do acesso e das condições de habitação procuram abranger, até 2008, 12700 famílias. Poderemos interrogar-nos se 5\% desta afectação fosse direccionada para famílias ciganas em situação de precariedade habitacional seria um passo decisivo para quebrar o ciclo de exclusão social destas famílias. 
Quadro 4: Metas e medidas inscritas no PNAI 2006-2008 que poderiam resolver as situações de carência habitacional por parte dos ciganos

\begin{tabular}{|c|c|c|c|}
\hline $\begin{array}{l}\text { Objectivos } \\
\text { da } \\
\text { intervenção }\end{array}$ & Medida de Política & População alvo & $\begin{array}{l}\text { N. }{ }^{o} \text { agregados } \\
\text { familiares/ } \\
\text { /projectos a } \\
\text { abranger }\end{array}$ \\
\hline \multirow{4}{*}{ 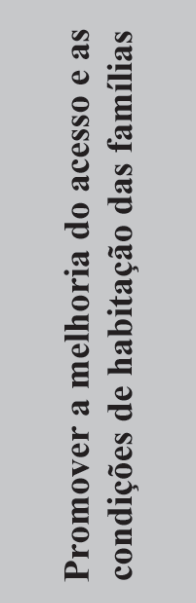 } & $\begin{array}{l}\text { PCHCC - Programa de } \\
\text { Apoio à Construção de } \\
\text { Habitação a custos } \\
\text { controlados }\end{array}$ & População em geral & 3200 famílias \\
\hline & $\begin{array}{l}\text { PER - Programa Especial de } \\
\text { Realojamento }\end{array}$ & $\begin{array}{l}\text { Famílias com graves carências } \\
\text { habitacionais }\end{array}$ & 3500 famílias \\
\hline & PROHABITA & $\begin{array}{l}\text { Famílias com graves carências } \\
\text { habitacionais }\end{array}$ & 3000 famílias \\
\hline & $\begin{array}{l}\text { Porta } 65 \text { - Gestão } \\
\text { Habitacional e } \\
\text { Arrendamento do Parque } \\
\text { Público * }\end{array}$ & $\begin{array}{l}\text { Famílias com dificuldades de } \\
\text { acesso à habitação através do } \\
\text { funcionamento do mercado }\end{array}$ & 3000 famílias \\
\hline \multirow{2}{*}{ 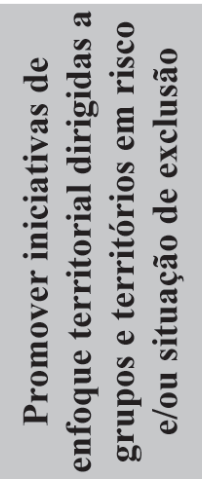 } & $\begin{array}{l}\text { PROGRIDE - Programa } \\
\text { para a Inclusão e } \\
\text { desenvolvimento }\end{array}$ & $\begin{array}{l}\text { Territórios; crianças e jovens } \\
\text { em risco, pessoas vítimas de } \\
\text { violência doméstica, sem- } \\
\text {-abrigo }\end{array}$ & 73 projectos \\
\hline & $\begin{array}{l}\text { CDS - Contratos de } \\
\text { Desenvolvimento Social* }\end{array}$ & $\begin{array}{l}\text { População de áreas críticas } \\
\text { metropolitanas e territórios } \\
\text { economicamente deprimidos e } \\
\text { desertificados }\end{array}$ & 30 contratos \\
\hline
\end{tabular}

Fonte: Plano Nacional de Acção para a Inclusão 2006-2008 - Portugal, pp. 106-109.

* Novas medidas.

Estando as cerca de 800 famílias já referenciadas a passar por um processo de exclusão habitacional de longa duração, tanto no domínio físico (condições inadequadas), como no domínio legal (inexistência de título legal de propriedade) e social (não ter um espaço adequado que garanta a privacidade individual e que possa ou não permitir as relações sociais), fica por esclarecer se estas famílias ganhassem o estatuto de sem-abrigo que medidas lhes poderiam ser aplicadas. Ter este estatuto implica adoptar uma noção de sem-abrigo mais alargada, tal como foi reconhecida por alguns países europeus (i.e., Áustria, Alemanha, Irlanda, Reino Unido). Para efeitos estatísticos estes países incluíram todos aqueles que por falta de meios ou qualquer outro motivo não têm acesso ao mercado de habitação. São, assim, contemplados aspectos visíveis (estar na rua ou em centros de acolhimento) e ocultos (casas inadequadas ou inseguras). Parte-se do pressuposto de que ser sem-abrigo é um continuum de situações que vai desde aqueles que não têm uma casa (rooflessness ou houselessness), até aos que têm um alojamento inadequado ou inseguro, pelo que são exigidas diferentes formas de decisão política e de intervenção (Edgar et al., 2003).

Nesta definição de sem-abrigo, os portugueses ciganos sem residência fixa estariam incluídos na categoria de habitações inadequadas que abrange as pessoas cuja acomodação é imprópria para habitação ou se regista sobrelotação ou têm um tipo de habitação móvel. Assim, no âmbito dos 73 pro- 
jectos que serão abrangidos pelo PROGRIDE, os critérios de selecção das candidaturas poderiam adoptar uma noção alargada de sem-abrigo no sentido de poder contemplar as situações já descritas.

\section{Considerações finais}

Ao longo deste artigo tivemos oportunidade de constatar como nos últimos anos têm persistido as situações de exclusão habitacional para algumas famílias ciganas e de como factores exógenos a esta população tendem a explicar este fenómeno. Esta exclusão habitacional acaba por se repercutir no acesso a outros direitos básicos de cidadania, mas também ao nível da configuração dos padrões de mobilidade dos portugueses ciganos. Isto porque diferentes posicionamentos geralmente manifestos por cientistas sociais, decisores políticos e outros actores com responsabilidade na gestão das questões sociais e urbanas têm obscurecido o conhecimento sobre os ciganos portugueses, ora por serem marcados por uma componente mistificadora e romântica da mobilidade espacial onde a sedentarização tende a traduzir uma ameaça à sua identidade étnica, ora por verem no nomadismo uma forma de desvio, sendo o sedentarismo o único modo de vida aceitável. Como vimos qualquer um destes posicionamentos acaba por se repercutir negativamente em termos das oportunidades que os ciganos encontram para uma inserção territorial estável. Vimos também que embora a nível local sejam identificados problemas e necessidades relacionados com a população cigana na área da habitação eles não têm tido tradução nos sucessivos Planos Nacionais de Acção para a Inclusão e nas medidas de política de habitação.

Através de algumas recomendações de organizações governamentais e não-governamentais procurámos ilustrar as condições por onde pode passar a mudança. Sintetizando, parece ser importante:

- Aprofundar o conhecimento/reconhecimento de famílias e grupos, no sentido de se compreender as ligações familiares, afectivas, sociais e administrativas a lugares e territórios;

- Evitar práticas de suspeição, vigilância e punição a investir num percurso que favoreça a desconstrução de estereótipos e promova uma coexistência mais harmoniosa;
- Adequar as boas experiências às especificidades dos contextos locais e à heterogeneidade das famílias, contando com o envolvimento da população cigana na manifestação/concretização das suas necessidades e expectativas e com o envolvimento de um conjunto de entidades no cumprimento das suas obrigações em matéria de inclusão social;

- Perante a identificação a nível local de necessidades de respostas diversas em termos habitacionais e os condicionalismos apresentados para a sua execução, importa reverter as necessidades identificadas localmente em soluções inscritas nas políticas de habitat;

- As políticas de habitação devem ser promovidas pelas entidades competentes, e implementadas em espaços adequados e viáveis, com infra-estruturas suficientes para o seu bom funcionamento, orientadas pelo princípio da criação de oportunidades de inclusão, devendo ser combatida qualquer forma de restrição ao acesso à habitação por razões de discriminação racial ou étnica.

As recomendações que foram sendo enunciadas revelam como a situação habitacional dos ciganos raramente é encarada como fazendo parte da política global de habitação, mas sim como um problema particular associado a este grupo, repercutindo-se na tendência para discutir medidas de compensação onde os ciganos poderão aparecer como grupo-alvo e preferencialmente através de apoios da União Europeia. Este posicionamento comporta riscos e a título de exemplo refira-se um caso na Eslováquia que teve como consequência uma limitação no acesso à habitação social, pois só podiam aceder caso determinado município dispusesse de um programa especial de habitação para ciganos (ERRC, et al., 2004: 31). Parece-nos, no entanto, que situações desta natureza poderiam ser controladas, retirando-se vantagens da aplicação destas medidas para territórios onde a pressão da opinião pública condiciona a acção política e da sociedade civil.

Encontramo-nos assim ao nível do debate sobre a necessidade de políticas de discriminação positiva, geralmente accionadas em caso de recurso perante os fracassos de medidas antidiferencialistas, pois parece evidente que o "marcador étnico" tem estado na origem das desi- 
gualdades sociais e nos processos de exclusão social (CNRM, 2002). Boaventura Sousa Santos enuncia os obstáculos e vias de solução para uma "articulação pós-moderna e multicultural das políticas de igualdade e de identidade" (Santos, 1999:44), já que a crise de gestão controlada dos sistemas de desigualdade e de exclusão na modernidade capitalista teve, pelo menos, o mérito de mostrar que o universalismo antidiferencialista além de não ser genuíno, reduziu as complexas relações entre igualdade e identidade, entre desigualdade e diferença (idem: 43-44).

\section{Anexo: Recomendações do Conselho da Europa para a promoção das condições habitacionais dos} ciganos

\begin{tabular}{|c|c|}
\hline & 1. Políticas integradas de habitação \\
\hline & 2. Princípio da não-discriminação \\
\hline & 3. Liberdade de escolha de modo de vida \\
\hline & 4. Habitação adequada e acessível \\
\hline$\hat{z}$ & $\begin{array}{l}\text { 5. Prevenção da exclusão e de criação de } \\
\text { guetos }\end{array}$ \\
\hline & 6. Participação \\
\hline & 7. Trabalho em rede \\
\hline & 8. Coordenação \\
\hline & 9. Papel das entidades locais e regionais \\
\hline
\end{tabular}

Assegurar que políticas de habitação integradas e apropriadas dirigidas aos ciganos são desenvolvidas, afectando-se recursos suficientes que contribuam para as políticas nacionais de redução da pobreza

Sendo os ciganos um dos grupos populacionais da Europa mais desfavorecidos, as políticas nacionais de habitação devem procurar envolver os seus problemas específicos com um carácter de urgência e de uma forma não discriminatória

Assegurar o direito das pessoas prosseguirem modos de vida sedentários ou nómadas. Devem ser garantidas todas as condições necessárias a estes modos de vida pelas entidades nacionais, regionais e locais de acordo com os recursos disponíveis, os direitos dos outros e o quadro legal de construção, ordenamento do território e de acesso a terrenos privados

Promover e proteger o direito a habitação adequada para todos, bem como ao seu acesso pelos ciganos, através de políticas adequadas e proactivas, particularmente na área da oferta de habitação a custos controlados e de serviços

Prevenir, proibir e quando necessário reverter políticas de âmbito nacional, regional ou local ou iniciativas que asseguram que não sejam relegados para espaços inapropriados, áreas ambientalmente perigosas ou para áreas escolhidas em função da sua etnia

Proporcionar às comunidades ciganas e organizações os meios para participarem no processo de concepção, desenho, implementação e monitorização de políticas e programas que visem qualificar a sua situação habitacional

Promover o empowerment e a capacidade de construção entre as comunidades ciganas, fomentando parcerias a nível local, regional e nacional nas políticas dirigidas aos problemas habitacionais dos ciganos e garantindo que as comunidades ciganas estão activamente envolvidas no processo

Assegurar uma coordenação adequada na área da habitação entre as entidades relevantes a nível nacional, regional e local e as populações ciganas e organizações em sua representação

Incentivar as entidades locais a cumprirem as suas obrigações relativamente aos ciganos na área da habitação, da mesma forma como para quaisquer outras pessoas com o mesmo estatuto legal. As entidades locais e regionais devem também ser incentivadas a que as estratégias de desenvolvimento local contenham objectivos concretos direccionados aos ciganos e às suas necessidades habitacionais

Fonte: Recomendação Rec(2005)4 do Comité de Ministros dos Estados-membros na promoção de condições habitacionais para os Roma e Viajantes na Europa, 23 de Fevereiro 2005, http://www.coe.int/t/dg3/romatravellers/ documentation/recommendations/rec(2005)4logement_fr.asp 


\section{Bibliografia}

ALBUQUERQUE, Rosana (2001), "A intervenção das autarquias. Inserção das comunidades ciganas" in SOS RACISMO, 2001, Ciganos, Números, Abordagens e Realidades, Lisboa, SOS Racismo, pp. 52-63.

AMIGUINHO, Abílio (1994), Caracterização sóciodemográfica e cultural da comunidade cigana no Alentejo, Centro Regional de Segurança Social do Alentejo, 197 p.

ANTUNES, Margarida; HENRIQUES, Luís; ROMANO, Ricardo; SANTOS, Marta (2007), Identificação e caracterização das famílias ciganas residentes nos bairros municipais de Lisboa - Lisboa ocidental, 1. ${ }^{\circ}$ Relatório, Lisboa, Gebalis, $72 \mathrm{p}$.

ASCHER, François (1998), Metapólis. Acerca do futuro da cidade, Oeiras, Celta, 1995.

ASSIER-ANDRIEU, Louis; GOTTMAN, Anne (coord.) (2003), Légiférer sur les 'gens du voyage'. Génese et mise en æuvre d'une législation, Centre d'Études Politiques de l'Europe Latine, Université de Montpellier 1.

AUBIN, Emmanuel (2003), La commune et les gens du voyage, Paris, Berger-Levrault.

BASTOS, José Gabriel Pereira; CORREIA, André Clareza; RODRIGUES, Elsa, 2006, Sintrenses Ciganos. Uma abordagem estrutural-dinâmica, Lisboa, CEMME/Câmara Municipal de Sintra.

CASTRO, Alexandra (2004), "Ciganos e itinerância. Uma aproximação à realidade concelhia e às suas formas de hospitalidade", Cidades, Comunidades e Territórios, n. ${ }^{\circ}$ 9, Lisboa, CET.

CASTRO, Alexandra (2006), "Ciganos, Territórios e Itinerância. Análise de um questionário enviado aos postos da Guarda Nacional Republicana", CET/FCT, Texto Policopiado, Novembro 2006.

CNRM (2002), Avaliação de Impactes do Rendimento Mínimo Garantido - Caracterização do perfil das Minorias Étnicas, Lisboa, IDS, - Colecção Estudos.

CORREIA, André (2007), “ «Filhos da estrada e do vento... e da miséria. Porque estas terras são todas deles» - Danos de um relacionamento desigual de longa data", paper apresentado no First International Conference of Young Urban Researchers, ISCTE, 11-12 Junho 07, Lisboa, disponível em: https://conferencias.iscte.pt/viewabstract.php?id=216\&cf $=3$

DROBENKO, Bernard (dir.) (2004), Territoires et minorités: la situation des gens du voyage, Limoges, Press Universitaire de Limoges, 231 p.

DUARTE, Isabel; CASTRO, Alexandra; AFONSO, Joana; SALGUEIRO, Margarida; ANTUNES, Maria José (2005), Coexistência inter-étnica, espaços e representações sociais: os ciganos vistos pelos outros, 2005, Lisboa, ACIME, Colecção Olhares n. ${ }^{\circ} 4,181 \mathrm{p}$.

DUARTE, Isabel; CASTRO, Alexandra; AFONSO, Joana; SOARES, Luís (2005a), Os ciganos vistos pelos outros: proximidade social em espaços de coexistência inter-étnica Relatório de Investigação, Texto Policopiado, Lisboa, CET/FCT, 163 p.
ERRC; ERIO; FOCUS CONSULTANCY (2004), La situation des rom dans une union européenne élargie, Luxemburgo, Comissão Europeia - Direction générale de l'emploi et des affaires sociales.

EDGAR, Bill et al., (2003), Review of statistics on homelessness in Europe, European Observatory on homelessness, FEANTSA.

ERCC/Númena (2007), Os serviços sociais ao serviço da inclusão social: o caso dos ciganos. Avaliando o impacto dos Planos Nacionais de Acção para a Inclusão Social na Republica Checa, em França e em Portugal, ERCC/Númena, 89 p.

ERCI (2002), Segundo Relatório sobre Portugal, European Commission Against Racisms and Intolerance, adoptado em 20 de Março de 2002, Estrasburgo, 4 Novembro 2002, 36 p.

FREITAS, Maria João (2007), "Habitação \& Cidadania", apresentação no Seminário "Caminhos para uma Política Social de Habitação”, Peniche, 25 Janeiro 2007.

Fórum Não Governamental para a Inclusão Social (2006), Plano Nacional de Acção para a Inclusão (2006-2008): Reacção do FNGIS, Dezembro de 2006, 6 p., disponível em http:/ /foruminclusao.no.sapo.pt/FNGIS_Reaccao_PNAI_2006-2008.pdf

GILLES, Marguerite (2001), "Nous, on a toujours les pieds quelque part! - voyage et territoire", Études Tsiganes, Vol. 15.

HUMEAU, J.-B. (1995), Tsiganes en France. De l'assignation au droi d'habiter, Paris, L'Harmattan.

HUMEAU, Jean-Baptiste (1997), "Place des tsiganes dans la ville", Territoires, n. ${ }^{\circ} 381$.

JANODET, L., FERREIRA, C., 1992, Les tsiganes et les gens du voyage dans la cité, L' Harmattan, Paris.

KENDALL, Sally (1997) "Sites of Resistance: Places on the Margin - the Traveller - 'Homeplace' in ACTON, Thomas, Gypsy Politics and Traveller Identity.

LACROIX, François (2004) "Territoires de vie et territoires institutionnels. Lieux et diversités en Ile de France" in DROBENKO, Bernard (dir.) Territoires et minorités: la situation des gens du voyage, Limoges, Presse Universitaire de Limoges.

MACHIELS, T. (2002, Garder la distance ou saisir les chances. Roms et gens du voyage en Europe occidentale, Réseau Européen contre le Racisme, $43 \mathrm{p}$.

MARQUES, C.; CORREIA, J.; REIS, M. F. (1996), Comunidade Cigana na Diocese de Lisboa, Lisboa, Secretariado Diocesano de Lisboa Obra Nacional para a Pastoral dos Ciganos/Departamento de Acção Social da Câmara Municipal de Lisboa, 163 p.

NAÇÕES UNIDAS - HABITAT (2003) The Habitat Agenda Goals and Principles, Commitments and the Global Plan of Action, disponível em: http://www.unhabitat.org/downloads/ docs/1176_6455_The_Habitat_Agenda.pdf 
NINER, Pat (2004), "Accommodating Nomadism? An Examination of Accommodation Options for Gypsies and Travellers in England", Housing Studies, Vol. 19, n. ${ }^{\circ} 2$.

NUNES, Olímpio (1981), O povo cigano, Lisboa, ONPC, $2 .^{\mathrm{a}}$ edição de 1996.

OBRA NACIONAL DA PASTORAL DOS CIGANOS (2000), Projecto Dignidade, Relatório Final, Lisboa, ONPC.

PROVOT, Bernard, (1987), "Les dessous d'un secret”, Études Tsiganes, n. ${ }^{\circ} 4$

PROVOT, Bernard (1995), "Stationnement et habitat: de la précarité à l'espace organisé", Hommes et migrations, n. ${ }^{\circ}$ 1188-1189, pp. 75-79.

PROVOT, Bernard (1998), "Stationner, résider, habiter. Plaidoyer pour le temps", Etudes Tsiganes, n. ${ }^{\circ} 11$.

PROVOT, Bernard (2004), “À travers la revue Études Tsiganes. Une réflexion de l'UNISAT sur le stationnement et l'habitat", Études Tsiganes, n. ${ }^{\circ} 17$.

REAPN (2003), "I Encontro Habitação e Comunidades Ciganas", in Ciganos.pt, Junho 2003
REAPN (2007), Guia para a Intervenção com a Comunidade Cigana nos Serviços de Saúde, Madrid, Fundacion Secretariado Gitano

ROBERT, Christophe, (2000), "Tsiganes et nomads", Informations Socials, n. ${ }^{\circ} 85$, pp. 60-69

SAMA, S. (2003), "La movilidad como forma de vida en la comunidad gitana de Evora: mitos e realidades" in BRANCO, J. F. e AFONSO, A. I. (org.) Retóricas sem Fronteiras, I/ mobilidades, Oeiras, Celta, pp. 53-70.

SANTOS, Boaventura Sousa (1999), A construção multicultural da igualdade e da diferença, Oficina do CES, $\mathrm{n}^{\mathrm{o}}$ 135, Janeiro 1999, $61 \mathrm{p}$.

SOS RACISMO (2001), Ciganos, Números, Abordagens e Realidades, Lisboa, SOS Racismo.

VASCONCELLOS, José Leite de, 1982 [s/d.], Etnografia Portuguesa, vol. IV, Lisboa, Imprensa Nacional - Casa da Moeda, pp. 351-419.

XUFRE, Maria Antonieta Vidal Vieira (2004), A Viagem dos Filhos da Estrada e do Vento. Ciganos Sedentarizados, Beja, Universidade Moderna. Pólo de Beja, no âmbito do seminário do curso de Investigação Social Aplicada, Mimeo. 